\title{
Chapter 1 \\ An Introduction to Climate-Smart Forestry in Mountain Regions
}

\author{
Roberto Tognetti, Melanie Smith, and Pietro Panzacchi
}

\begin{abstract}
The goal to limit the increase in global temperature below $2{ }^{\circ} \mathrm{C}$ requires reaching a balance between anthropogenic emissions and reductions (sinks) in the second half of this century. As carbon sinks, forests can potentially play an important role in carbon capture. The Paris Agreement (2015) requires signatory countries to reduce deforestation, while conserving and enhancing carbon sinks. Innovative approaches may help foresters take up climate-smart management methods and identify measures for scaling purposes. The EU's funding instrument COST has supported the Action CLIMO (Climate-Smart Forestry in Mountain Regions CA15226), with the aim of reorienting forestry in mountain areas to challenge the adverse impacts of climate change.

Funded by the EU's Horizon 2020, CLIMO has brought together scientists and experts in continental and regional focus assessments through a cross-sectoral approach, facilitating the implementation of climate objectives. CLIMO has provided scientific analysis on issues including criteria and indicators, growth dynamics, management prescriptions, long-term perspectives, monitoring technologies, economic impacts, and governance tools. This book addresses different combinations of CLIMO's driving/primary objectives and discusses smarter ways to develop forestry and monitor forests under current environmental changes, affecting forest ecosystems.
\end{abstract}

\footnotetext{
R. Tognetti ( $\triangle)$

Dipartimento di Agricoltura, Ambiente e Alimenti, Università degli Studi del Molise,

Campobasso, Italy

e-mail: tognetti@unimol.it

M. Smith

Inverness College, University of Highlands and Islands, Inverness, UK

e-mail: melanie.smith.ic@uhi.ac.uk

P. Panzacchi

Department of Biosciences and Territory, Università degli Studi del Molise, Pesche, Italy

Faculty of Science and Technology, Free University of Bolzano-Bozen, Bolzano, Italy
} 


\subsection{Forests and Climate Change}

The recent report of IPCC on climate change, desertification, land degradation, sustainable land management, food security, and greenhouse gas (GHG) fluxes in terrestrial ecosystems (IPCC 2019) highlights a considerable increase in mean land surface air temperature, since the preindustrial period, even in comparison with the global mean surface temperature. In parallel, an estimated $23 \%$ of total anthropogenic GHG emissions has occurred in the decade 2007-2016, due to agriculture, forestry, and other land uses, which affects more than $70 \%$ of the land surface (22\% for managed and plantation forests). Curtis et al. (2018) calculated that $27 \%$ of global forest loss in the 2001-2015 period was due to deforestation, through permanent land use change for commodity production. In the remaining areas, which maintained the same land use, forest loss was attributed to forestry operations $(26 \%)$, shifting agriculture (24\%), forest fires $(23 \%)$, and urban expansion $(0.6 \%)$. Forest management strategies may interact with climate forces other than GHG (e.g., surface albedo, canopy roughness, biogenic emissions, stand evapotranspiration). Indeed, changing forest species composition may affect the emissions of biogenic volatile organic compounds, and the formation of secondary organic aerosols, which, in turn, have warming and cooling effects, depending on time, location, and type of emission (Šimpraga et al. 2019). Generally, deciduous trees have higher reflectivity (albedo), with consequent reduced warming effect, than conifer species. This is nuanced by different forest types and management intensities having different albedos, depending on the degree of exposure of the forest floor toward the atmosphere, particularly when covered by snow.

Climate change has already caused many changes in forest ecosystems and negative effects prevail, including warming-induced shifts in species distribution (Lindner et al. 2010; Boisvert-Marsh et al. 2014) and drought-related increases in tree mortality (Allen et al. 2010; Cailleret et al. 2017). Impacts of climate change magnify local disturbances (Fig. 1.1), such as environmental pollution, nitrogen deposition, habitat fragmentation, forest fire, pest outbreak, and alien species, altering forest development trajectories and decreasing capacity for resistance (Millar and Stephenson 2015; Johnstone et al. 2016). The climate emergency challenges traditional silvicultural strategies that have evolved through hundreds of years of relative climate stability. This indicates the necessity of developing and adopting the adaptable management framework of climate-smart forestry (CSF).

Climate-smart forestry is forestry that sustainably raises timber productivity (production), increases resilience (adaptation), stores carbon (mitigation), and enhances the achievement of development goals. Climate-smart forestry involves monitoring forest functions and anticipating disturbance effects, while undertaking resilient actions to avoid the negative consequences on the provision of ecosystem services and forest productivity (Bowditch et al. 2020). Climate-smart forest structure and functions require flexible silvicultural approaches, which may address mitigation needs and adaptation circumstances at different spatial scales. Climatesmart forestry, as defined in Chap. 2 of this book (Weatherall et al. 2021), can be 


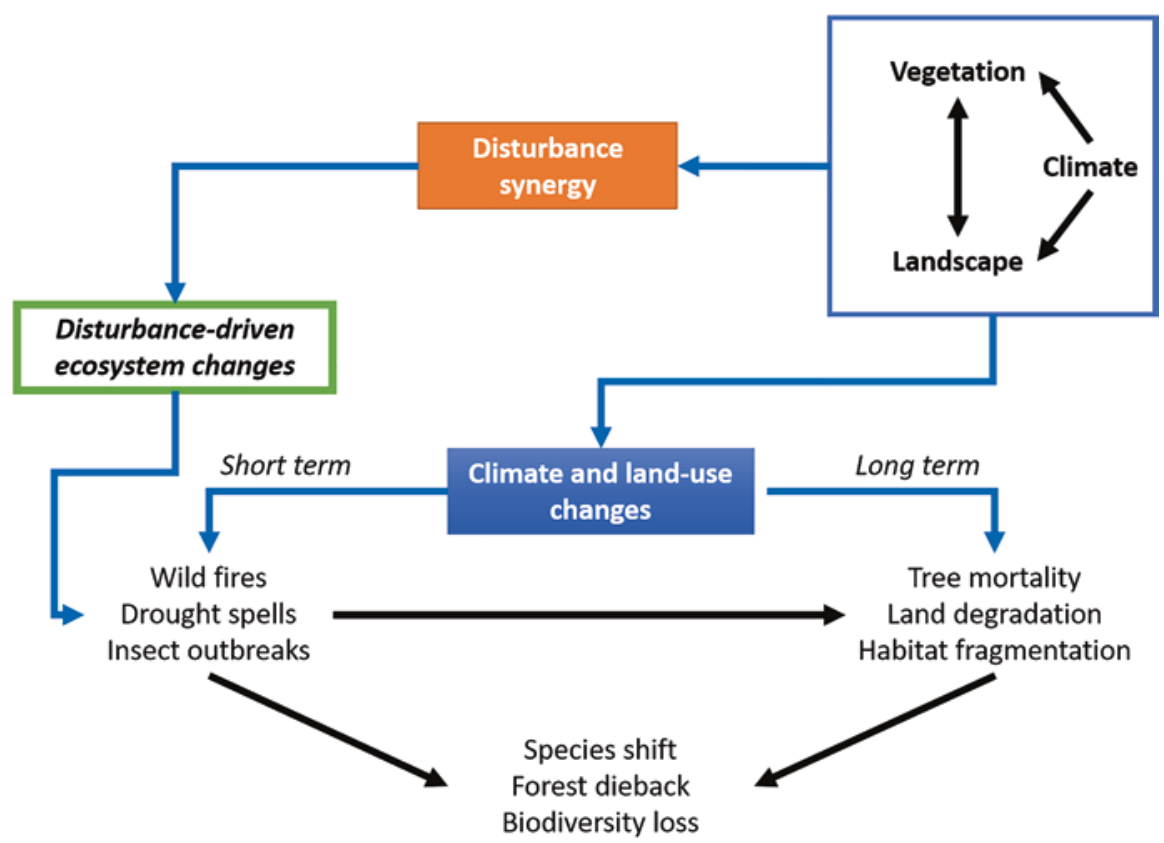

Fig. 1.1 Conceptual and empirical models that address the impacts of climate and land-use changes on forest vulnerability need to focus on landscape dynamics and vegetation processes, integrating disturbance strategies

considered a toolbox for sustainable management of forests, where the goal is to increase the resilience to environmental disturbance, reduce the deviation from natural structure, and use the wood for carbon storage.

All the climate drivers and relevant sectors (including forestry, agriculture, energy, transportation, industry, construction) should be considered, when studying the contribution of land use and biomass systems in reducing the radiative forcing in the atmosphere over varying time scales. Yet, the interaction among climate change, human activities, and ecosystem processes (e.g., forest aging and natural disturbances), as well as the capacity of forests to sequester and store carbon over time, needs to be addressed for all biogeographic regions. In doing this, the climate impact of CSF, considering $\mathrm{CO}_{2}$ and other GHG, the effects of albedo and evapotranspiration, biogenic emissions, and the various aspects related to biodiversity and resilience, needs to be assessed and monitored (Fig. 1.1). Engaging forest managers, policy makers, and relevant stakeholders is central to ensure applicability of CSF at different levels (local to European), and to pursue the integration with forest inventory data and decision support systems.

The Paris Agreement sets the global warming target to be "well below $+2{ }^{\circ} \mathrm{C}$ compared to the preindustrial levels." In order to achieve this, the Parties have given voluntary pledges to decrease their net emissions of GHG (the so-called Intended Nationally Determined Contributions - INDCs). The latter are clearly not enough to 
reach the $+2{ }^{\circ} \mathrm{C}$ target, and extra efforts are required as soon as possible. Nevertheless, the Paris Agreement endorsed the role of forests as the most important carbon sink that can be managed to balance emissions and removals. Therefore, forest management should aim to reduce $\mathrm{CO}_{2}$ concentration in the atmosphere (Articles 4 and 5), as well as the radiative imbalance at the top of the atmosphere (Article 2), without raising the air temperature or decreasing the precipitation amount (Article 7). While forests subject to prevailing natural drivers are regarded as representing the baseline, most of the European forestland is the result of millennia of human activities, a dynamic mosaic of disturbance and recovery (Sabatini et al. 2018). Significant contribution for meeting the Paris Agreement goals may derive from silvicultural activities (e.g., reforestation, conservation, management) (Griscom et al. 2017). Demand for forest goods and services is growing in the local, regional, and global context; at the same time, however, the negative impact of climate change on forests is increasing and alternative management approaches need to be employed to avoid the risk of exceeding thresholds for global chronic stress (Hartmann et al. 2018), stability of long-term ecological processes (Hanewinkel et al. 2013), and discrete disturbance events (Seidl et al. 2014). Fostering mixed-species and structural heterogeneous forests to preserve productivity (e.g., Hilmers et al. 2019; Torresan et al. 2020) and/or a balanced mosaic forest landscape, combining intensification of sustainable forest production with retention of high value habitats for biodiversity conservation (Ceddia et al. 2014), may provide an efficient solution in countries with high quality of governance, and a template exemplar for others.

\subsection{A Climate-Smart Perspective: Becoming Climate Smart}

Trees and forests are passively subject to climate, but are also able to dynamically modify it, providing important ecosystem services. Indeed, although 5-10 $\mathrm{GtCO}_{2} \mathrm{e}$ per year come from deforestation and forest degradation, forest protection and the reduction of forest degradation represent effective mitigation options, in terms of social and environmental benefits $\left(0.4-5.8 \mathrm{Gt} \mathrm{CO}_{2} \mathrm{e}\right.$ per year). Therefore, to maximize the climate benefits of forests, more forest landscapes should be maintained, and objectives set to restore those lost (Fig. 1.2). Overall, forest should be managed more sustainably. Managing forests to more closely recall the structure, function, and composition of natural forests, compared with traditional approaches, has been the goal of several silvicultural frameworks aimed to sustain the productivity of healthy forests and to maintain the provision of ecosystem services across successional stages (e.g., Seymour and Hunter 1999; Franklin et al. 2007; Puettmann et al. 2015).

Traditionally, the main objective of forest management has been to harvest timber Puettmann et al. 2009), often converting uneven-aged mixed-species stands to even-aged homogeneous monocultures, mimicking an agricultural approach, increasing the standing volume, volume increment, and allowable cut. The transformation of ecological functions (e.g., watershed conservation, soil retention, 


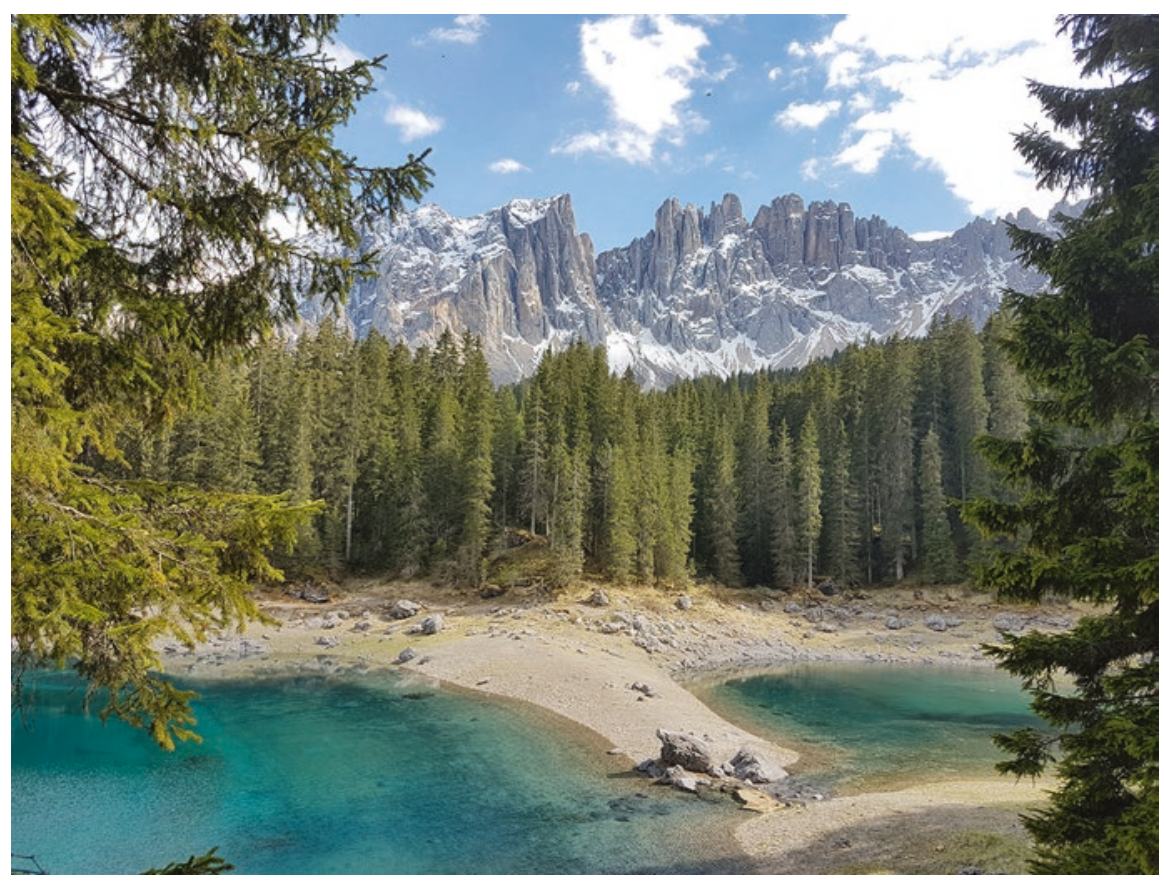

Fig. 1.2 Lago di Carezza (1534 $\mathrm{m}$ a.s.1.) and the Latemar forest, a typical multifunctional landscape of the Dolomites (Italy)

biodiversity protection, carbon sequestration) into environmental services occurs when people take benefits. Nevertheless, society has historically focused on timber commodity chains and nonwood forest products, neglecting most environmental services. Recently, a growing interest has emerged in achieving multiple Sustainable Development Goals (SDGs) through effective interactions or synergies among measures and policies (Rio + 20 conference in 2012). In particular, the urgent need of mitigating climate change has led to promote forest protection (SDG 15) in order to accumulate carbon in trees and soils, and, therefore, mitigate climate change (SDG 13). Diversification and flexibility of production systems are considered crucial approaches for increasing resilience of forests to natural disturbances.

More forest area than ever since the Middle Ages, although tree cover cannot accurately assess the surface of forest ecosystems, poses high expectation on the European forest sector (Nabuurs et al. 2019). Large mitigation effects from forest in the European Union (EU) can be expected by increasing sequestration potentials and through substitution effects (Grassi et al. 2019). However, reducing temperature increase through forestry (mitigation) may have a limited effect on climate (Fig. 1.3), since trade-offs exist between options to meet climate objectives (Luyssaert et al. 2018). Therefore, a question arises on whether shifting forest management from timber-oriented approaches to CSF should privilege adaptation (climate prospect) rather than mitigation (carbon view), particularly in the vulnerable mountain landscape (Fig. 1.3). Forest ecosystems and local circumstances of European mountains 


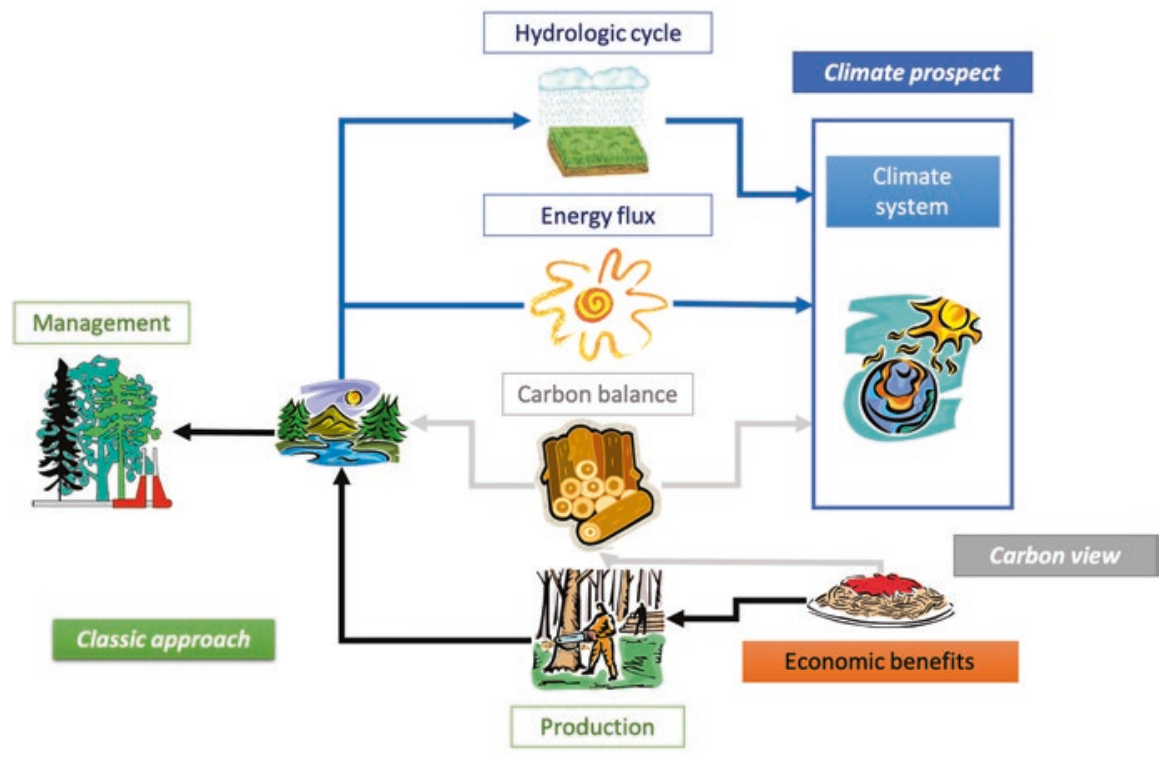

Fig. 1.3 Forests store large amounts of carbon in tree biomass, understory vegetation, and soil compartments, but mitigation may have poor effect on climate

are well suited to address questions associated with climate-smart potentials of the forest sector (European Environment Agency. 2016). Locally tailored CSF measures need to minimize trade-offs among bioeconomy, adaptation (biodiversity, disturbance), and mitigation (carbon, substitution) options. In Europe, $41 \%$ of mountain areas are covered by forests providing diverse ecosystem services, with an impact both at local communities' scale and at regional scale (Price et al. 2011).

Nabuurs et al. (2018), following the Climate-Smart Agriculture concept developed by FAO, proposed a CSF approach for European forests, suggesting safeguarding the mitigation potential of forests against climate change through an array of regionally tailored measures. Kauppi et al. (2018), focusing on bioeconomy issues and policy instruments, stressed the need to tackle multiple policy goals with CSF, by reducing or removing GHG emissions, adapting and building forest resilience, and sustainably increasing forest productivity and incomes. Verkerk et al. (2020), trying to indicate possible synergies between the mitigation and adaptation pillars of CSF with other forest functions, considered the sustainable climate mitigation potential of the whole forest and wood product chain, including material and energy substitution and accounting for local circumstances. However, the implementation of CSF approaches and the establishment of disturbance-resilient forest systems have not yet become rooted in silvicultural practices and with forest operators that promote sustainable forest management, consequently some significant open questions remain:

- How to implement adaptation, mitigation, and production options in forestry systems, in synergy with the development of bioeconomy and the preservation of biodiversity? 
- How to achieve multifunctional landscapes, through addressing the sustainable provision of environmental services to accomplish the tenure security of ownership rights?

- How to interconnect local circumstances, opportunities, and challenges with governance goals to reap the potential of the forest sector in meeting the climate targets?

Forest managers that want to meet climate change issues through sustainable forest management practices will need to plan at multiple spatial and temporal scales and operate with multidisciplinary approaches and design flexibility (Innes 2009). Threats to forest ecosystems can be reduced by increasing the adaptive capacity, resilience strength, and resource-use efficiency of forestry systems. Although forest managers have always dealt with patchiness in environmental conditions, particularly in mountain areas, the escalation in climatic variation at the global level and the increase in uncertainty at the local scale call for more flexible and rapid response capacity.

A comprehensive definition of CSF and the process for selecting suitable indicators of climate-smartness were proposed by Bowditch et al. (2020). Adaptation and mitigation issues, as well as the social dimension, were the core focus of this definition, which recognizes the need to integrate and avoid development of these aspects in isolation. The need for integration derives from the complementarity of the resilience concepts in forestry, quantified as the recovery time after a disturbance (Nikinmaa et al. 2020): engineering, ecological, and social-ecological resilience. The complexity of social-ecological and practical challenges, associated with changing climate, disturbance, and governance, results in difficulties for forest managers in applying resilience concepts and CSF. The COST Action CLIMO (ClimateSmart Forestry in Mountain Regions) started responding to these multifaceted needs by laying the foundations of long-term experimental forest sites in mountain areas, which aim to facilitate the exchange of knowledge and practice and build forest manager-scientist partnerships.

Climate-smart forestry fosters the integration of scientific knowledge, technical skill, and policy action toward smart prospects through learning, monitoring, planning, coordinating, supporting, and financing the road to resilient forest systems and flexible management strategies (Fig. 1.4). Involving local communities and administrations in participatory design of specific solutions has a key role in fostering successful policies and actions. Operating forestry systems to accomplish climate targets follows the three pillars of CSF:

1. The development of mitigation opportunities for carbon sequestration in forests

2. The advancement of adaptation strategies for resilience to climate change

3. The intensification of socio-ecological sustainability for natural resource management

Although these three pillars of CSF require common consideration, the relative importance of each objective may vary locally, as much as trade-offs and synergies do (Lipper et al. 2014). 


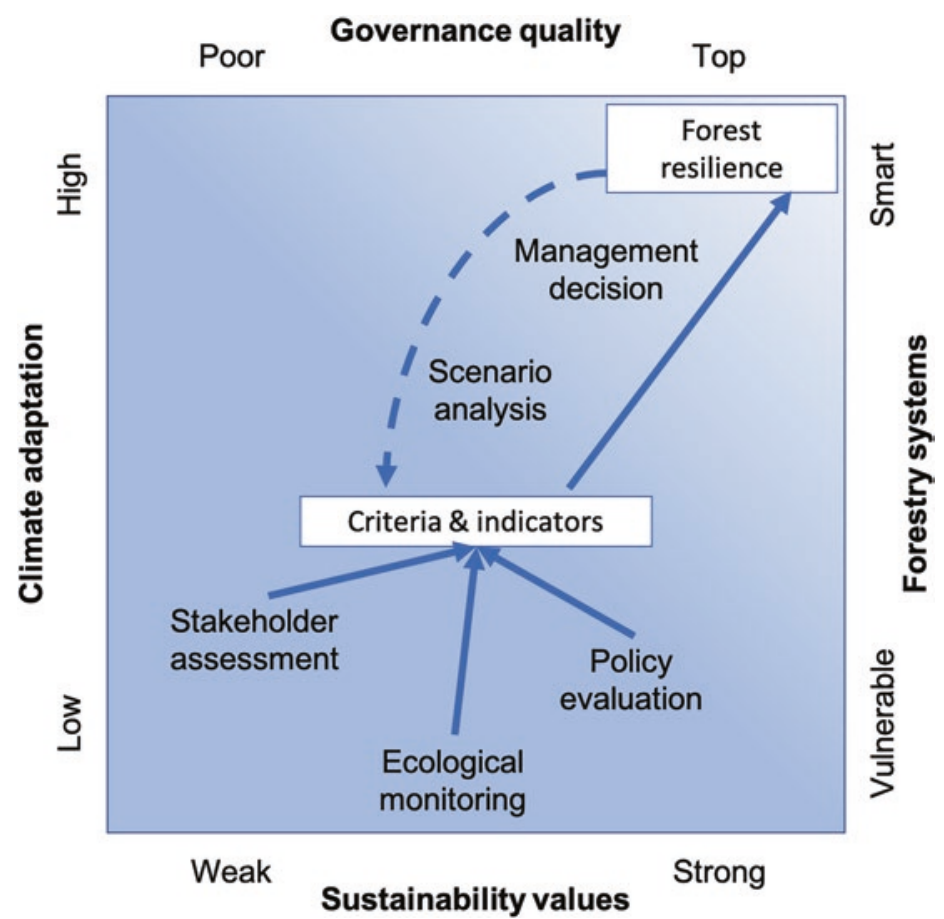

Fig. 1.4 Linking values to sustainability with climate smartness of the forestry system

Through effective knowledge exchange with forest managers and the entire sector, forestry research has the potential to reorient management practices and utilization approaches, as well as to develop evidence-based policy for CSF. In this context, CSF builds on well-established sustainable forest management approaches, for example, close-to-nature forestry (Bauhus et al. 2013), continuous-cover forestry (Pommerening and Murphy 2004), ecological forestry (Franklin et al. 2007), adaptive silviculture (Nagel et al. 2017), and systemic silviculture (Ciancio and Nocentini 2011). Combinative approaches have been developed to coordinate diverse management objectives on the same land, aimed at satisfying multiple societal demands (Aggestam et al. 2020); conversely, segregative approaches to land use target the maximization of specific objectives in separate spatial contexts (Phalan et al. 2011). To meet the increasing demand for ecosystem services, forestry needs to consider territorial-specific potentialities and limitations, and land-allocation procedures (Messier et al. 2019). Climate-smart forestry may also encompass sustainable intensification on abandoned agricultural land, for mitigation purposes (e.g., short-rotation forestry), and the establishment or strengthening of protected forest areas to compensate for the loss or degradation of biodiversity. Indeed, rapidly changing climatic conditions and land uses call for continuous updating of forestry practice through innovation, knowledge exchange, and learning. Whether land sharing or land sparing may better limit environmental impacts, ensuring the supply of goods, is still a 
matter of debate. Some agricultural studies argue that more intensive and efficient farming would increase farm productivity on reduced farmed hectarage, this would reduce the total land required for agriculture, and release land for other ecosystem services, for example, biodiversity, flood mitigation, and carbon capture. (Phalan et al. 2016). In contrast, other studies claim that low-intensity agriculture can satisfy the increased demand for food, while promoting biodiversity and other ecosystem services (Tscharntke et al. 2012). The latter approach has been traditionally implemented in the EU's agricultural schemes to compensate potential loss of income by farmers who mitigate detrimental effects of intensification on biodiversity. As forests are planted on agricultural land for carbon capture and nature conservation, there is a need to understand and plan how these forests integrate into emerging dynamic landscapes. Recently, Messier et al. (2019) have proposed to integrate functional diversity and redundancy concepts into complex spatial network approaches, as an adaptable strategy to manage forest systems at multiple scales. This strategy can be further informed through reference to true long-term ecological data.

\subsection{Referencing True Long-Term Ecological Data for CSF}

Key to achieving the goals of climate-smart forestry is an understanding of how species assemblages respond to environmental change. Accessing comprehensive long-term ecological data is an important part of building this understanding (Pretzsch et al. 2017; del Río et al. 2021), but until recently, "long term" generally referred to data sets of decadal records. However, true long-term ecological (tLTE) data encompasses millennial scale information (Willis et al. 2010; Rull 2014), drawing upon transdisciplinary sources including paleoecology, archeology, and history (Fig. 1.5). The epochal scale of the climate change now underway demands consideration of the last time such changes occurred, for example, at the end of the

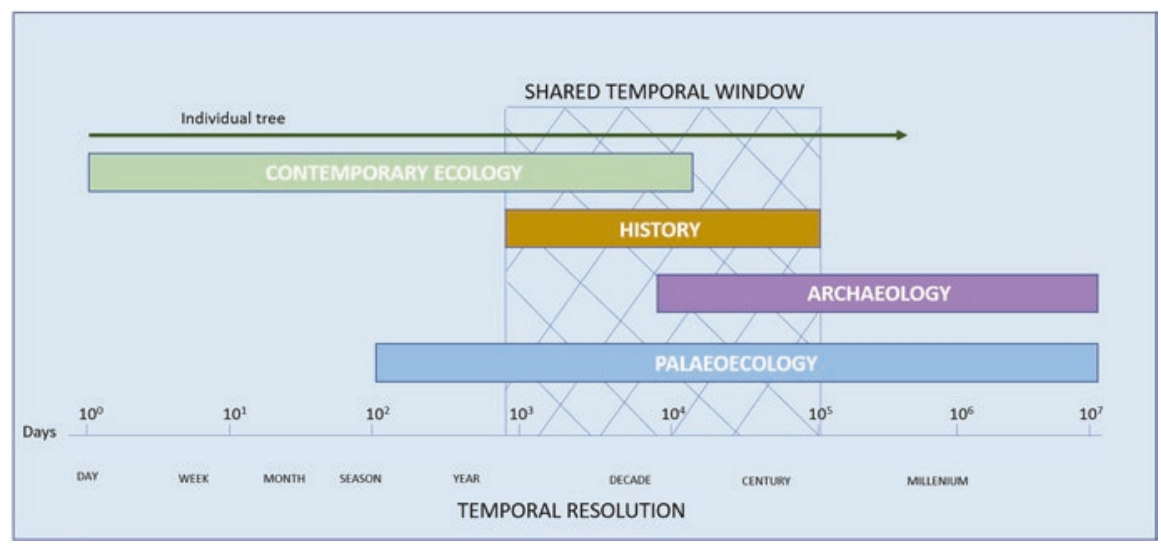

Fig. 1.5 Shared window of temporal evidence sources. (Adapted from Rull 2014) 
last ice age. It also demands conceptual tools for analyzing how plant species assemble into communities.

Messier et al. (2019) describe one set of tools based on the notions of functional diversity and functional redundancy. High diversity in functional traits (e.g., between gymnosperms and angiosperms) can be achieved through the presence of just two species within a forest stand, but in such a stand, the functional redundancy is potentially low, because the functional traits are only represented by each of the two species. If one species disappears, the entire representation of those functional traits also disappears. High functional diversity and redundancy can be achieved where several different species in the same stand display the same functional traits. By viewing tLTE evidence through the lens of functional trait analyses, it may be possible to infer how species and populations responded to past climatically induced disturbances. Hamilton et al. (2018) discuss and identify some of the challenges to furthering the field of functional paleoecology and resilience, primarily the need to identify traits that are ecologically meaningful and quantifiable in the sediment record. However, considerable advances in techniques to improve taxonomic resolution are now ready to address some of these challenges. For example, Bálint et al. (2018) describe the application of environmental DNA, (eDNA) from sediments to create continuous time series to resolve ecological dynamics and move toward the harmonization of multidisciplinary data (Fig. 1.5).

Davies et al. (2017) show the response of vegetation over long-time series to microclimatic variations between upland and lowland sites, with local site conditions variously influencing the degree and trajectory of vegetation response to climate shifts. Analysis of the palynological record shows that where high functional diversity and redundancy are evident, the forest has greater capacity to change composition, maintenance of continuous canopy cover, and thus resilience. This suggests that tLTE can indicate the temporal and spatial scales at which complex adaptive forest systems can most effectively deal with changing conditions and unpredicted disturbances. Bonsall et al. (2020) attempt to assess ecosystem resilience measured by the role of mycorrhizal association in a plantnitrogen dynamic model in a long-time series palaeoecological record. This demonstrates the potential of synthesizing plant nutrient modelling and palaeoecological data, but also highlights the significant challenges and questions that still need to be addressed.

tLTE information can be used to enhance understanding of forests as complex adaptive systems, informing close to nature forestry (Bauhus et al. 2013; Nocentini 2015), as well as becoming a standard in the toolkit for CSF. The functional complex network approach (Messier et al. 2019) is a useful framework for focusing the techniques for synthesis and analysis of tLTE data, and with the addition of new techniques, such as eDNA, there is the opportunity to more effectively inform CSF practice. 


\subsection{Integrating Forest Disturbance and Ecological Stability}

Forests are increasingly challenged by changing environmental conditions and growing societal demands. Forest managers and authorities, responsible for forestry operation and decision making, are required to address multiple, sometimes conflicting, objectives, such as the provision of forest products, the conservation of biodiversity, and the sequestration of carbon. To tackle these issues, novel management strategies, planning guidance, and policy recommendations are needed, at stand and regional scales. However, stakeholders and decision makers lack simple indicators to assess the suitability of forest ecosystems to achieve the vast array of objectives facing global change. This shortcoming hinders the adoption of appropriate strategies and may cause forest policy and management to be inadequate for addressing multiple future challenges. The strength of CLIMO is the network of long-term experimental plots, with detailed structural data, which generate operational examples of management options for merging silvicultural strategies with environmental changes and the social dimension (Fig. 1.6). In this context, engaging stakeholders will be central in developing, testing, and refining local-level indicators of "smartness," and producing a practical toolkit to help implement CSF.

Forest dynamics are changing globally, because of the interplay between the increasing anthropogenic impact on the environment and the changing course of natural disturbances. In Europe, during the twentieth century, tree growth and forest area have been enhanced by the fertilization effect of $\mathrm{CO}_{2}$ and the cessation of deforestation, though there are signs of carbon sink saturation in forest biomass (Nabuurs et al. 2013). Legacies of past silvicultural practices have resulted in altered forest composition, often favoring species more vulnerable to drought (e.g.,

On scope of resistance
- Maintain the species
richness and ecosystem
complexity in mountain
landscapes
- Encourage forest natural
regeneration and tree
species mixture to
support existing food
web interactions
- Retain soil fertility,
preserve water storage
capacity, and maintain
structural and biotic
integrity

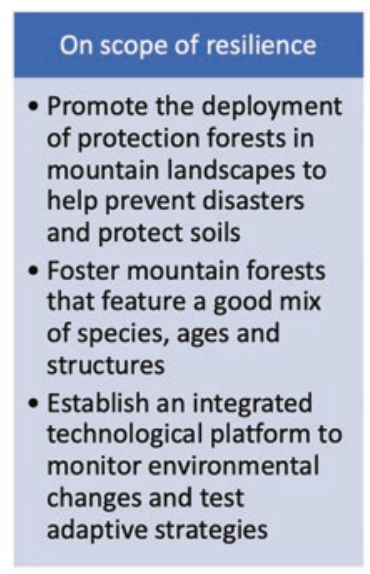

On scope of sustainability

- Propose innovative
schemes of PES useful to
develop policies
supporting the delivery
of ecosystem services
- Encourage the
incorporation of climate
impact in mountain
forestry investment
projects
- Endorse the inclusion of
climate-smart mountain
forests in REDD+
strategies and finance

Fig. 1.6 Important recommendations for decision makers, who need to consider the major contribution of emission reductions per produced unit and the consequences of carbon sink saturation of mountain forests, when sustaining the mitigation potential of forests in mountain landscapes 
European beech, Norway spruce), which adds to increase in warming-induced evaporative demand. Accelerating processes of increased tree mortality, indeed, are apparently forcing forests to become both younger and shorter (McDowell et al. 2020). Climate-smart forestry warrants to address the consequences of the shifts in forest dynamics related to these changes, considering multiple plant traits associated with drought resilience and additional stress agents (Coble et al. 2017).

Uncertain climatic conditions and erratic extreme events warrant careful consideration of synergies and trade-offs among mitigation, adaptation, biodiversity conservation, and provisioning of ecosystem services. Accordingly, CSF management strategies need to be customized to match the different ecological and social contexts, assessing the interconnected implications. The complex dynamics of forest ecosystems and rapidly accelerating environmental changes increase the uncertainty of historical knowledge and require novel management approaches and silvicultural operations to maintain forest integrity and halt the loss of resilience (Pretzsch et al. 2020). Yet, the shift in societal expectations and growing socioeconomic disparity, on one hand, add to the simplification of forest structures and increasing forest fragmentation, on the other, making long-term landscape planning difficult (Messier et al. 2019). Managing forests for uncertainty calls for approaches able to adapt promptly and flexibly, and that change in accordance with unexpected (even extreme) events (Millar et al. 2007).

Flexible forest management approaches have been proposed to address accelerating environmental and societal challenges, including disturbance-based management (Franklin et al. 2007), complexity-related management (Puettmann et al. 2009), and mixed-forest management (Bravo-Oviedo et al. 2018). These approaches try to incorporate principles of natural forest dynamics, including the role of disturbances in generating the landscape mosaics, applying silvicultural practices and operations that limit the impact of forest management on environmental functions and services. Managing forests as natural infrastructures, within a matrix of diverse land cover types, may provide appropriate "nature-based solutions" for balancing integration and segregation processes in the landscape mosaics, with respect to different ecological and social contexts. Facing climate change requires, however, a rethinking of current forest management challenges that promote adaptive (resistance, resilience, and response options) and mitigation strategies, while maintaining current goals (e.g., wood production, biodiversity conservation, carbon sequestration, water provision, social value) under uncertain climate scenarios (Nagel et al. 2017; Kauppi et al. 2018; Bowditch et al. 2020). In a few words, management should assure the stability and sustainability of forest ecosystems (Larsen 1995) (Fig. 1.7). Mimicking disturbance regimes with forestry practices needs trend analysis to extract an underlying pattern or time series analysis to deal with data collected over time.

Trend detection helps determine whether there has been a departure from the background or historical conditions (see Chap. 6: Pretzsch et al. 2021b), whereas trend estimation is useful to quantify the nature of the change and investigate models that provide the interpretation of the triggering process. To assess short- and long-term impacts of climate change on forest resilience and implement indicators 


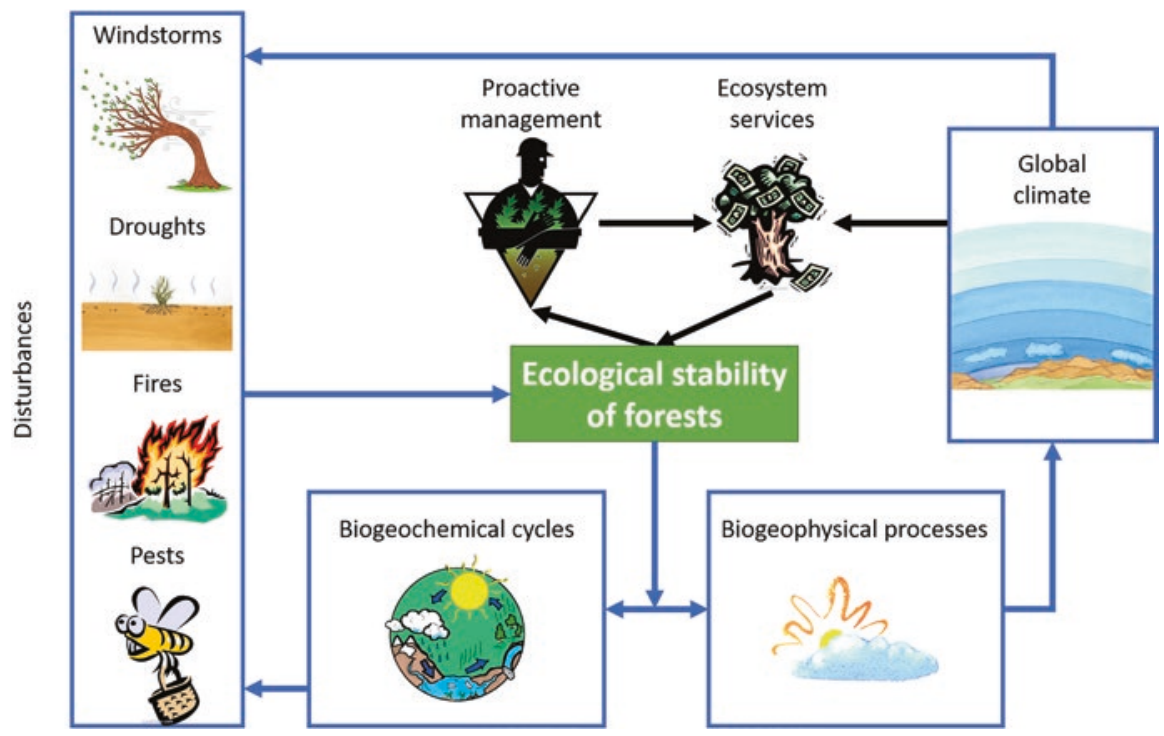

Fig. 1.7 A climate-smart perspective considers the ecological stability of forests, which comprehends resistance and resilience, and therefore, synergies between climate and other benefits, and between adaptation and mitigation. The interlinkages between the three dimensions of CSF (stability, productivity, flexibility) need to be taken into consideration for a holistic approach to any management transformation

of climate-smart forest management and utilization, as well as decision support tools, for adapting forest systems to changing environmental conditions (Santopuoli et al. 2020), quality monitoring of permanent plots is mandatory (see Chaps. 3 and 4: del Río et al. 2021; Temperli et al. 2021). Yet, to identify major drivers of forest change and improve the quality of data, time series and forest inventory analyses can be integrated with enhanced long-term controlled experiments (see Chap. 10: Tognetti et al. 2021) and further scaled geographically (see Chap. 11: Torresan et al. 2021). Comparing historical versus current performance, a network of plots for major forest species (monocultures vs. admixtures) established along adaptation gradients may allow accommodate a range of potential tree growth trajectories, across a variety of ecosystem types and geographic regions, for being used at an operational spatial scale (see Chaps. 5 and 6: Pretzsch et al. 2021a, b). Data collected in permanent plots, designed as long-term studies, together with tLTE data (see Sect. 1.3), can be used to parametrize growth models to facilitate testing species responses to climate change and CSF patterns (see Chap. 7: Bosela et al. 2021). Forest managers and landscape planners facing climate-related uncertainty and unknown forest dynamics require operational examples to inform decision-making processes and prepare forest ecosystems and silvicultural recommendations for climate-driven and socially driven challenges (see Chaps. 8 and 9: Pach et al. 2021; Picchi et al. 2021). 
To inform climate-smart decision making in forest management and utilization, valuable demonstrations are needed, integrating multiscale indicators to compare and shape proactive strategies, testing alternative management approaches, conveying the silvicultural implications of climate change, and identifying locally to regionally appropriate planning processes (see Chap. 13: Bottaro and Pettenella 2021). For generating policy instruments that foster climate-smart responses to uncertain environmental prospects, interaction between scientists and stakeholders (forest owners, managers, practitioners, etc.) is compulsory (see Chap. 14: Dubova et al. 2021). The science-policy partnerships may advance communication on CSF at the continental to global scale, across countries, weighing the cobenefits and side effects between climate regulation and other ecosystem services (see Chaps. 15, 16, 17: Vizzarri et al. 2021; Pappas et al. 2021; Giongo Alves et al. 2021). Examples of climate-smart measures include managing forest disturbances and extreme events, selecting resilient trees, implementing forest reserves (high-nature value, HNV), combining carbon storage, sequestration, and substitution, using forest bioenergy and wood in the construction sector, and valuing ecosystems and their services with the objective that help halt land degradation. Payment for environmental services and other forms of monetary incentives may support long-term ecologic, economic, and social perspectives of CSF, particularly when involving local communities, and aligning social norms with personal values (see Chaps. 12 and 13: Gežík et al. 2021; Bottaro and Pettenella 2021).

\subsection{The Climate-Smart Forestry Framework}

Climate is a dynamic system that is in equilibrium, driven by the amount of energy. However, if the amount of energy kept by the atmosphere from sunlight increases, then climate changes. The exchange of energy, water, and $\mathrm{CO}_{2}$ within forests influences climate, interacting with the atmosphere. Anthropogenic impact on forests (land cover) alters biogeochemical (carbon cycle) and biogeophysical (albedo and evapotranspiration) cycles, in turn changing the global climate (Bonan 2008). Forest-atmosphere-human interactions cause complex climate forcing, feedback, and response (IPCC 2019). Since rapid changes in external factors (e.g., land cover, GHG concentration) may push the climate system into a new mode, the resulting augmented level of uncertainty requires urgent actions to increase the resilience of forests (Vose et al. 2018). Increasing frequency and magnitude of forest disturbances, as well as long-term changes in vegetation dynamics, add concern for forest productivity, health, and biodiversity and, consequently, for the provision of ecosystem services. Mostly, the knowledge of forest-climate interactions comes from models that strive to simulate complex physical, chemical, and biological processes. Nevertheless, understanding of forest functioning needs to be gained from sitespecific permanent sample plots, and management solutions for resilience tested across biogeographic regions (Fig. 1.8). 


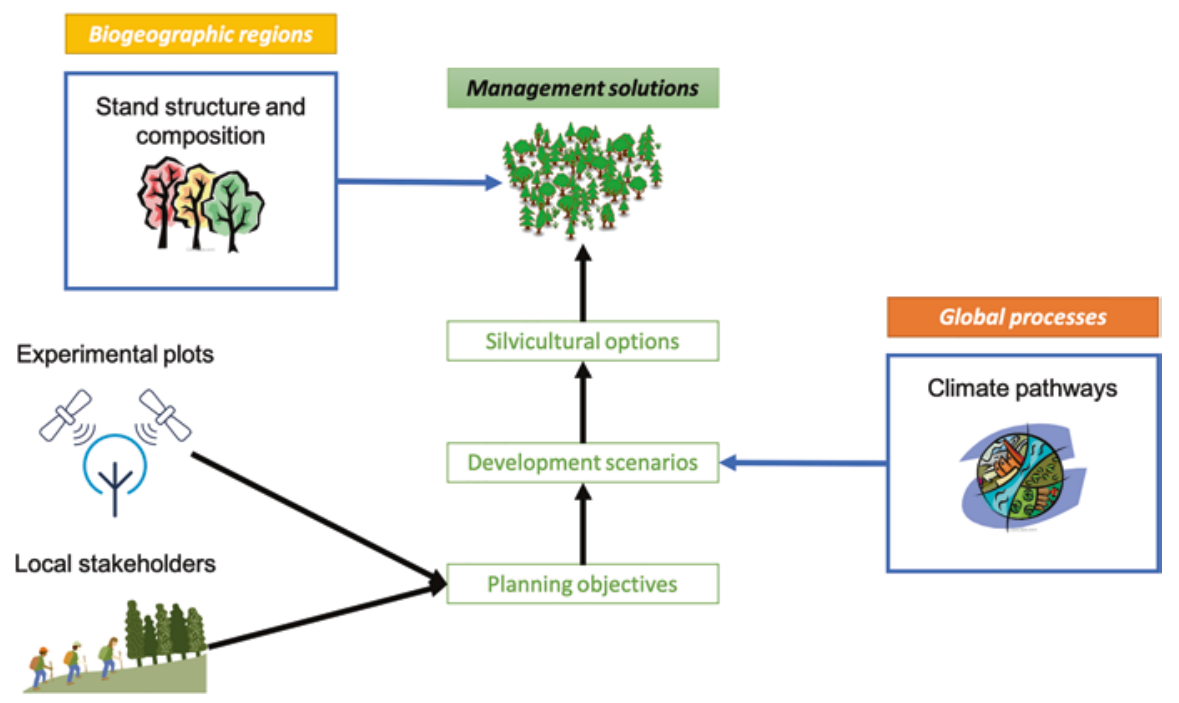

Fig. 1.8 Stakeholder engagement and experimental input to develop adaptable CSF solutions in different biogeographic regions

Technological advances in manufacturing miniaturized machine tools and Internet network connecting systems have prompted the development of cyberinfrastructures to address ecological questions (Rundel et al. 2009; Torresan et al. 2021). The use of satellite imagery and statistical modelling has recently allowed the generation of a spatially continuous map of forest tree density at a global scale (Crowther et al. 2015). Being able to count the global sum of trees, a question emerges: can we monitor a representative number of individual trees as biogeo-physical-chemical units of major forest types and/or biogeographic areas?

To cope with increasing societal demands on forests, a holistic view of the options is essential, including the provision of wood and nonwood products, as well as biodiversity and other ecosystem services. Therefore, suitable climate-smart indicators, for evaluating and monitoring forests and forestry in relation to their adaptation to changes in disturbance regime and intensity, require to be implemented to assure a stable provision of forest products and ecosystem services (Bowditch et al. 2020; Santopuoli et al. 2020; see also Chap. 2 of this book, Weatherall et al. 2021). Indicators can be conveniently used to develop management tools and design novel forest systems, and continuously monitored to measure progress. European mountain systems are experiencing forest colonization and densification due to land abandonment and, as such, represent good standards to identify restoration targets and segregative instruments, considering a range of opportunities, risks, and constraints of the forest value chain in the long run. In this context, the view that mountain forests provide services for lowland uses should be replaced with a perspective focused on forest health and resilience per se, and on strategies to reduce forest vulnerability to changing environment, in order to strengthen the protective functions of these forests. 
Promoting climate-smart governance of mountain forests requires testing: (i) whether local experiences on forest systems influence manager-environment interactions to meet real goals (expert partnership), (ii) how research methods help understand the relationships between forests and stakeholders and the feasibility of silvicultural options (stakeholder dialogue), (iii) whether the monitoring of forests helps the understanding of past-present relations while envisioning future forest conditions (scientific contribution), (iv) how the learning process facilitates the generation of novel silvicultural approaches and the interpretation of existing knowledge (manager training), and what trade-offs exist between mitigation of and adaptation to climate change, and between biodiversity conservation and forest production (Ogden and Innes 2007). Disturbance impacts vary locally and need adaptation and communication strategies at different levels (Lindner et al. 2014), reconciling global issues and regional objectives, which requires an interdisciplinary approach toward understanding forest systems, dissemination of quantitative evaluation to forest stakeholders, as well as planning and managing forests sustainably for the long term.

Long-term effects and efficacy of designed smart-management strategies need to be addressed, considering current policy and future consequences on forests. A participatory approach with forest managers, landowners, decision makers, local communities, and the forest industry is, therefore, crucial to implement CSF practices at the stand and landscape scales. To this aim, simple indicators to assess the suitability of forest ecosystems to achieve the multiple demands made on these systems and appropriate tools to quantify these challenges are needed to tailor local policies and incentives. A multiscale indicator approach may help integrate the research strands (long-term experimental plots, region-specific case studies), management options, silvicultural guidelines, and advanced modelling with stakeholder panels.

A CSF network needs to be integrated with that of protected areas (Natura 2000, national schemes), particularly with segregated old-growth forests. Remaining primary forests are the richest terrestrial ecosystems in biodiversity, and keep removing carbon from the atmosphere, while storing significant carbon stocks in biomass and soils (Luyssaert et al. 2008). A trans-biogeographic network of climate-smart and old-growth forest nodes connected by ecological corridors may generate a green infrastructure of healthy terrestrial ecosystems at the European scale. This strategy requires an effort in the restoration of damaged landscapes (including afforestation and reforestation in support of ecosystem restoration), ensuring the long-term productivity of forest capital and the ecological value of natural habitats. Promoting the health and diversity of forest ecosystems increases the sector's resilience to climate change, disturbance risk and economic crisis, while creating green job opportunities, for example, in small fruit farming or in forest therapy activities.

In parallel with segregation of high nature value landscapes, sustainable intensification through scientific and technological innovations is important in landscape zoning that maximizes the efficiency of production and reduces the competition for land. In this sense, the sustainable use of forest biomass for energy production and the shift toward advanced biofuels based on residues, as well as the efficient use of 
wood-based products for substitution purposes (the use of wood fuel in place of fossil fuels, for energy, and the use of wood fiber in place of cement, etc., whose production emits large amounts of $\mathrm{CO}_{2}$ ), have great potential for the long-term reduction of carbon emissions. An important challenge is represented by the need of integrating biomass production and nature conservation into forest management, as well as implementing European forest policy (Aggestam et al. 2020).

Changes in disturbance regimes (Seidl et al. 2016), in a cascade effect, may affect tree growth, stand structure, species composition, and regeneration processes, that is, forest dynamics, potentially impairing the purposes of forest management. Consequently, habitat conservation, timber supply, carbon stock, nontimber products, recreation, infrastructure safety, and cultural values can also suffer the consequences of multiple simultaneous changes. An integrated approach is, therefore, needed to reconcile critical trade-offs between the multiple goals of forest management, and direct adaptation measures in regions with a long legacy of land uses and cover changes, such as Europe. Because of the uncertain scenarios, disturbance risk monitoring and early warning recommendations are an important means of improving the efficiency of decision-making process and climate-smart support (Millar et al. 2007).

\subsection{A European Way to Climate-Smart Forestry}

Achieving food security and avoiding climate change are two major goals of our time (FAO 2013). Since deforestation and forest degradation account for about $12 \%$ of global anthropogenic carbon emissions, forests, forestry, and the whole forestbased sector play an important role in providing sustainable solutions to halting climate change. Forests and other wooded land cover at least $43 \%$ of the surface of the EU (28 countries; 182 million hectares), and the forest sector employs at least half a million European citizens directly and 2.6 million indirectly. Forests, the forest-based sector, and the bioeconomy have a crucial role in meeting the goals of the European Green Deal and EU's climate, energy, and environmental objectives. Yet, the EU's international commitments, such as the UN SDGs, Kyoto Protocol, and Paris Agreement, are impossible to achieve without climate benefits of multifunctional resilient forests, CSF, and ecosystem services provided by forests. Indeed, the EU Forest Strategy needs to address the continuous evolving policy options (e.g., referring to Bioeconomy Strategy, Deforestation Action Plan, 2030 Climate and Energy Framework) (Fig. 1.9).

The EU Forest Strategy needs to deploy innovation in support of rural development and scale up the role of the forest industry, while protecting the environment and ensuring circularity. Therefore, forest owners and local administrations, including regional governments, have a key part to play in strengthening CSF. Through sustainable development plans and local bioeconomy strategies, regional governments may support the deployment of renewable energy and promote entrepreneurship in the forest sector (Fig. 1.10). The EU regulation emphasizes the role of forests 


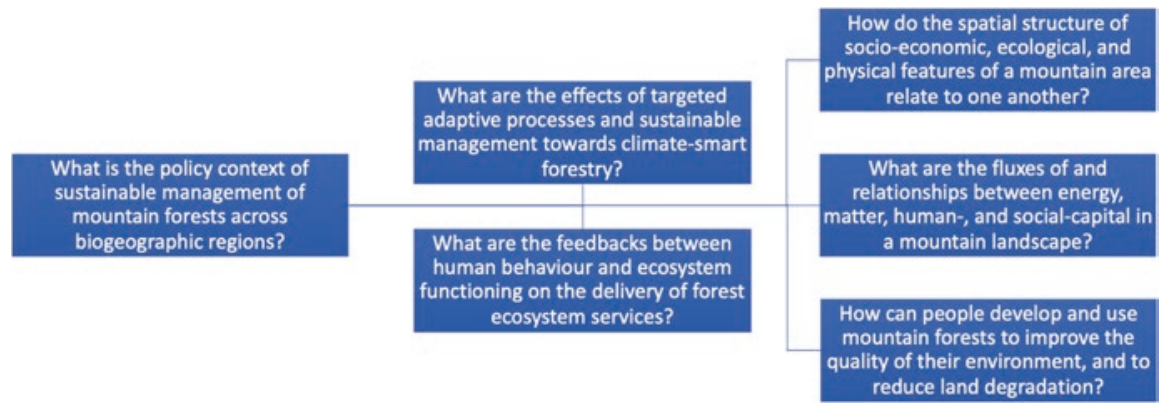

Fig. 1.9 Driving questions and principles toward a green economy in European mountain regions
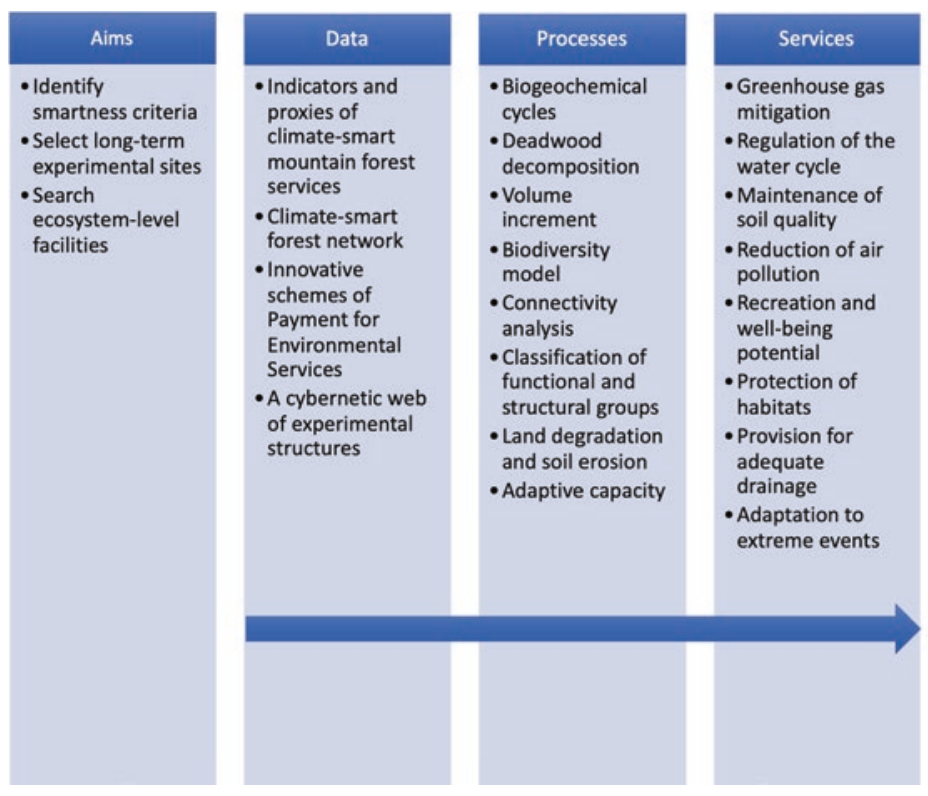

Impacts
- Increased
resilience of green
infrastructures of
mountain areas
- Dissemination
programs in
fostering an
understanding of
climate-smart
forestry among
stakeholders
- Integration of
policies with
feedbacks
between social
and
biophysical
processes based
on ecosystem
services and
disservices
- Mountain forest
sustainability
plans
- Increased
property values
and human health

Fig. 1.10 Conceptual structure of smartness-related actions and flow chart of ecosystem service quantification

and wood in reducing emissions and in carbon sequestration, further underpinning CSF. Yet, Member States have national or sectoral adaptation strategies to climate change. The European Forest Strategy also emphasizes the potential of forest management plans, or equivalent instruments, for a balanced delivery of ecosystem services and forest products.

Long-term data sets are critical for detecting patterns in environmental disturbance and trends in forest resilience. Forest health and tree productivity in permanent plots serve as benchmarks against which change in the response to natural and anthropic impacts on the landscape can be gauged. A network of biogeographically distributed permanent plots has the potential to serve as a long-term multisite 
platform for detection of environmental change over time, for forests of Europe. A strategy for implementing a multisensor platform, or modernizing existing infrastructures in forest ecosystems, requires developing low-cost wireless technologies for the collection and transmittal of data at the local to continental scales. Permanent plots are also useful for monitoring biodiversity. The pandemic of 2020 (COVID-19) highlighted how forest degradation (biodiversity loss) and landscape fragmentation (habitat loss) might increase the risk of infectious diseases. Curbing interference with natural ecosystems and restoring functionality in resilient forests are factors in preventing the spread of infectious disease outbreaks. Changes in the opportunity space for pathogens may facilitate mixing of infectious agents and expand grouping of potential hosts.

The new growth strategy of the EU (The European Green Deal) has the ambition to transform the Union into a resource-efficient, green, and competitive low-carbon society. The bioeconomy approach, based on renewable biological resources and sustainable bio-based solutions, offers a unique opportunity to address these complex and interconnected challenges. Appropriate indicators may help address possibilities and uncertainties related to the potential capacity of forest resources in contributing to the sustainable development of bioeconomy (Wolfslehner et al. 2016). Key indicators and monitoring tools need to consider differences in forest resources and management approaches among biogeographic regions and Member States. A continuous update of monitoring instruments and the adaptation of general principles to local circumstances are necessary to integrate decision-making processes. Autonomous wireless sensor networks, connected and communicating with each other, may measure relevant parameters within an area at many sites simultaneously, for a detailed picture about the environmental conditions on site and the early stages of tree response (Bayne et al. 2017). Forest managers, in general, do not have access to low-cost and high-frequency measurements of productivity-related parameters and, therefore, they can hardly be able to monitor the changeable conditions and complex interrelationships in forest stands. Combination of automated sensor networks of monitored trees, collecting key management data in real time, with UAV (Unmanned Aerial Vehicle) and multi-/hyperspectral remote sensing, will benefit transfer information wireless with LPWAN (low-power wide-area network) - LoRa (Long Range) and satellite communication, as well as allow forest inventory based on single tree measurements.

Different regions in Europe can be classified for the purpose of drawing down structural incentives to establish and play CSF actions. This analysis can be based on detailed criteria specific to each site and defined to identify thresholds for future silvicultural actions (Table 1.1). In this sense, the establishment of qualified partnerships is essential to effectively design and implement permanent sample plots, connecting research staff, forest managers, policy makers to develop, test, and monitor climate-smart management approaches. Information on the impacts of climate change on forestry systems is also required to build on the present status of sustainable forest management and develop climate-smart measures. Partnership needs to be adaptable to local circumstances and able to share costs and benefits associated with research activities and development plans. 
Table 1.1 Challenges and opportunities for CSF (and the wood industry) to align research activities with development plans at the local to European scales

\begin{tabular}{|c|c|}
\hline Silvicultural traditions & $\begin{array}{l}\text { Complement advanced tradition with local specificity, balancing } \\
\text { supply and demand }\end{array}$ \\
\hline Wood resources & $\begin{array}{l}\text { Consider forest structure, tree species, size distribution, forest } \\
\text { fragmentation. }\end{array}$ \\
\hline Certification bodies & Develop the implementation of forest certification schemes. \\
\hline Forest ownership & $\begin{array}{l}\text { Reduce fragmentation of forest ownership and incentivize } \\
\text { entrepreneurship. }\end{array}$ \\
\hline Data availability & $\begin{array}{l}\text { Harmonize forest inventories and monitor the results of alternative } \\
\text { treatment. }\end{array}$ \\
\hline Forest roads & $\begin{array}{l}\text { Improve the quality of road network and mobilization of forest } \\
\text { products. }\end{array}$ \\
\hline Forest industries & $\begin{array}{l}\text { Distribute costs and benefits between private and public bodies, } \\
\text { and rise competitiveness. }\end{array}$ \\
\hline Service networks & $\begin{array}{l}\text { Expand the utilization of innovations and the accessibility to digital } \\
\text { platforms. }\end{array}$ \\
\hline Support systems & Adopt decision support systems for forestry performance. \\
\hline Data digitization & $\begin{array}{l}\text { Increase the quality of data and their accessibility to small and } \\
\text { medium enterprises. }\end{array}$ \\
\hline Local communities & $\begin{array}{l}\text { Dialogue with associations, cooperatives, consortia, and other } \\
\text { stakeholders. }\end{array}$ \\
\hline Governance quality & $\begin{array}{l}\text { Ponder management agencies, institutional incentives, public } \\
\text { policies. }\end{array}$ \\
\hline Value-chain development & $\begin{array}{l}\text { Increase the degree of mechanization, capacity of investment, and } \\
\text { multifunctional material. }\end{array}$ \\
\hline $\begin{array}{l}\text { Nongovernmental } \\
\text { organizations }\end{array}$ & $\begin{array}{l}\text { Balance landscape intensification vs. ecosystem services, nature } \\
\text { conservation. }\end{array}$ \\
\hline Technical skills & $\begin{array}{l}\text { Progress the formation of forest practitioners and education } \\
\text { programs. }\end{array}$ \\
\hline Communication tools & Interpret public opinion and tackle administrative constraints. \\
\hline Production value & $\begin{array}{l}\text { Challenge market requirements and support new and high-quality } \\
\text { products. }\end{array}$ \\
\hline Cross-sectoral cooperation & $\begin{array}{l}\text { Integration with agriculture and environment, and expansion of } \\
\text { bioeconomy. }\end{array}$ \\
\hline
\end{tabular}

Urban areas host already complex networks of digital infrastructures. The socialpolitical focus on emerging digital technologies and smart cities risks leaving rural territories behind, preventing forest managers from using e-services, particularly if operating in mountain environments. Environmental discrimination is an increasingly growing phenomenon, poorly addressed in forestry research, posing urban dwellers and rural communities as dichotomous categories. Nevertheless, the proliferation of technology-driven initiatives requires balancing the interests of elite players with the concerns of local stakeholders (Gabrys 2020). Many efforts, from local to global initiatives (e.g., Bonn Challenge, Initiative 20x20, AFR100 African Forest Landscape Restoration Initiative, and The United Nations General Assembly declared 2021-2030 the United Nations Decade on Ecosystem Restoration) are 
underway to support the restoration of degraded forest landscapes and present Internet of Things (IoT) as necessary to meet global change targets. Therefore, companies that provide technology relevant for precision forestry may try to get benefits from ecological restoration initiatives, though criticism raises owing to the possible disconnection between people and nature, as well as the requirements of intellectual, financial, and material resources necessary for collecting, processing, and interpreting data.

\subsection{Pilot Forests}

Long-term experiments and permanent plots, addressing consequences of changing environmental conditions and disturbance regimes to ensure sustainable forestry, have been generally planned for local targets and with specific designs (tree growth, stand productivity). Networks of complex research infrastructures, such as the ESFRI (European Strategy Forum on Research Infrastructures) infrastructure ICOS-Integrated Carbon Observing System (www.icos-ri.eu), may provide the basis for a deeper understanding of forest ecosystem functioning (Rebmann et al. 2018). These infrastructures, designed for long-term monitoring of sources and sinks of GHG, have several disadvantages, including the relatively high personnel costs, installation difficulties, power requirements, managing skills, and maintenance needs. At these experimental stations, the principal technique for measuring ecosystem-atmosphere exchange of $\mathrm{CO}_{2}$ and $\mathrm{H}_{2} \mathrm{O}$ at the stand scale (forest level) is the eddy covariance, which is an evolution of physiological measurements of gas exchange in individual leaves (organ level). Nevertheless, integrated measurements of $\mathrm{CO}_{2}$ and $\mathrm{H}_{2} \mathrm{O}$ fluxes at the tree level (stem enlargement, tree transpiration) are gaining new perspectives (Steppe et al. 2015; Valentini et al. 2019). Applying a modular approach would be extremely useful to combine various monitoring tools and contribute toward CSF.

Advances in sensor technology, wireless communications, and software applications have enabled the development of low-cost, low-power multifunctional environmental sensors and sensor networks that can communicate forest conditions to researchers, managers, and the public in real time. These sensors generate information at unprecedented temporal and spatial scales, and offer transformational opportunities to better understand the physical, chemical, and biological "pulse" of forest ecosystems. Ground data can be coupled with remote sensing. For example, multitemporal monitoring of forest growth patterns on a plot scale across phenological stages using light detection and ranging (LiDAR) data and the use of remotely sensed sun-induced chlorophyll fluorescence (SIF) for tracking forest photosynthesis offer great potential to follow changes in gross primary productivity (GPP) of forests (Brocks et al. 2016). Wireless sensor nodes designed to provide interoperability with space observations, inventory data, meteorological records, and forest operations might reduce uncertainties and increase reliability of CSF indicators (see Chaps. 9, 10 and 11 of this book: Picchi et al. 2021; Tognetti et al. 2021; Torresan 
et al. 2021). These real-time "windows on mountain forests" also provide compelling new ways to engage the public and provide novel tools for resource managers. They may influence the forestry sector to meet the scientific and technological challenges emerging in mountain environments, providing solutions for proactive silviculture, while bringing trees closer to people (serba me, servabo te).

Traditional systems to collect basic information of forest functioning are labor intensive and the delivery of data to end users is slow, although reliable, data collection is of difficult expansion in time and space. In addition, traditional systems do not respond to environmental changes in real time. In this sense, IoT (Internet of Things) tools for data collection, processing, visualization, and device management provide an integrated technological platform for advanced monitoring of forests. A vision for a comprehensive redesign and standardization of environmental data collection and delivery at experimental sites is critically needed. Deployment of cyber technology can be envisaged in selected experimental forests, in order to develop a network of sites in which trees are monitored intensively and over time. Collecting long-term data sets is critical for detecting patterns and trends in climate-productivity relationships in health forests and responding to tree mortality issues.

The establishment of a permanent network of coordinated and distributed climate-smart forests, in which to test pre- and postdisturbance data collection, requires a substantial organization capacity and a preliminary analysis of environmental conditions and forest settings (Halbritter et al. 2020). This helps develop future scenarios and hypothesizes alternative management options, which can be assessed in local circumstances, following cost-benefit analysis. Continuously monitoring of forest functions and ecosystem services in long-term sampling plots is recommended. Climate-smart forestry and its placement into forest management decision processes need support for addressing trade-offs and synergies (Fig. 1.11).

Technological advances do not come without risks. Climate-smart sensor networks with wireless communication links are keys to monitor tree functions, forest conditions, and forestry operations. A CSF network should include a common suite of low-cost sensors for data collection, real-time data delivery to single web access points, and interactive data visualizations. However, wireless sensors deployed in forest stands still need improvements for data collection, transmission, control, and processing. Processors enabling continuous measurement and real-time storage of data are not always low-cost solutions for forest monitoring and forestry applications. Coordination and standardization of measuring methods and sampling protocols across different sites for establishing CSF networks is also a difficult task. Large amounts of data generated in long-term monitoring studies and their accessibility require property right analysis (Clarke et al. 2011), in order to make the best use of information related to the forestry sector. Ground-level data obtained from sensor nodes need to be related to stand structural complexity and scaled to forest management units by means of statistical modeling and remote sensing (e.g., UAV imagery), for being operative. However, environmental conditions near the ground (due to vegetation and topography) affect tree function and stand structure, and hardly represent a realistic picture of the tree-environment or stand-environment interface (Zellweger et al. 2019). 


Practices
- Criteria and
indicators to guide
climate-smart
forestry practices
are needed for
different
biogeographic
regions
- Integrated
landscape
management
approach is
crucial
- Efforts are needed
in involving key
local experts,
filling knowledge
gaps, monitoring
management
systems

Sites
- Long-term, field-
scale experimental
manipulation
facilities are
needed
- Information on
forest responses to
interactive effects
of disturbances is
crucial
- Efforts are needed
in establishing
low-cost
monitoring
platforms,
operating
permanent
sampling sites,
ensuring platform
flexibility

Technologies
- Standardized
technology for
collection and
transmittal of data
is needed
- Near real-time
access to
environmental
sensor data from
core sites is crucial
- Efforts are needed
in using a dynamic
ecosystem
approach, applying
data quality
assurance
procedure,
handling and
storing data
openly

Stakeholders

- Participatory approach, through a sustained dialogue between actors, is needed

- Involvement of local forest managers and regional authorities is crucial

- Efforts are needed in sharing assessment plans, including local expert partners, incorporating insights from past reference conditions

Fig. 1.11 Key messages in support of CSF

Electronic data collection requires a continuous data flow from the sensor network. Gaps may derive from instrument failures, power interruptions and bad weather, or instrument problems and maintenance stops (Rundel et al. 2009). Therefore, gap-filling techniques are required to produce continuous data time series (Moffat et al. 2007). Sensors and devices expose themselves to aspects of environmental conditions and material features that may degrade data integrity, making calibration an essential process. Poor calibration may also cause damage to hardware and the general infrastructure. Therefore, achieving good-quality data and maintaining error-free data collection in wireless sensor networks is challenging and calibration is essential to limit environmental noise and hardware failure (Barcelo-Ordinas et al. 2019). Energy consumption and sensor connectivity in wireless sensor networks are also crucial issues for the network effectiveness and efficiency in terms of lifetime, cost, and operation. Finally, the deployment of devices in CSF sites will require experienced and well-trained forestry personnel, which may cause digital inequalities due to the shift of control from traditional actors to elite services.

Forest monitoring detects the impacts and trends of climate change, natural disturbances, and human activities and is an essential element in CSF schemes. Legacies of natural disturbance and land use direct stand development and monitoring and understanding their role are keys to implement management techniques that contribute to maintaining forest stability (Franklin et al. 2007). Disturbance legacies and ecosystem conditions comprise ecological memory (Johnstone et al. 2016), which contributes to draw the trajectories of forest reorganization after disturbance 
(Jõgiste et al. 2018). Forest monitoring must be flexible, adapting tools and methodologies to the targeted objectives and biogeographic regions, for effective reporting and harmonization. Because of the time lag between management actions and ecosystem responses, essential elements of forest monitoring are a common set of indicators, a remote sensing system, a network of experimental plots, and a national forest inventory. To report policy makers on the implementation of CSF and provide forest managers with evidence on smart-adaptation strategies, a decision support tool is required for dealing with the challenges.

Protecting infrastructures, producing timber, safeguarding habitats, and allowing recreation are consolidated objectives in mountain forests in Europe, and establishing climate-smart targets in response to projected impacts and vulnerabilities requires commitment to long-term, large-scale research collaboration and manager partnership. Highly instrumented sites and permanent sampling plots are both needed to identify silvicultural strategies tailored to the various biogeographic regions. Since new prescriptions may deviate from those practitioners traditionally use, an expert and stakeholder training dialogue approach needs to be searched in cooperation with local experts and key stakeholders, in order to encompass the need of balancing the different demands on forests through CSF (Tognetti et al. 2017). Discussion panels may seek to answer specific questions or build consensus about management objectives.

Although experimental sites (permanent plots, instrumented sites) exist at the national level, and can be sampled to gain data and test models, as well as provide insights on tree responses over time, there can be limitations, due to the original study target and design (Fig. 1.12).

Building on previous experience and knowledge, new studies may develop local approaches further, specifically addressing the response of trees and the resilience of forests to disturbance in the context of climate change. Indeed, while HNV forests can be used as a benchmark for restoring managed forests, to some extent (Jandl et al. 2018), climate change may push ecosystems beyond historical limits (Millar et al. 2014; Dumroese et al. 2015). Novel information may contribute to and deliver a range of prescriptions according to experience and expertise in sustainable forest management, though durable commitments and consistent resources are required to ensure long-term operativity and development of management options.

Certainly, flexible forest management strategies are highly desirable to tackle spatially and temporally variable environmental conditions, with the aim of maintaining species mixtures, complex structures, and multiple functions of forests, as a way of enhancing the resilience to natural disturbances (Franklin et al. 2007; Puettmann et al. 2009; O'Hara and Ramage 2013), on a local basis over time. As an example, in locations where there are recurrent extreme events, for example, windstorms, a decrease in the growing stock can also be envisaged to reduce the vulnerability of the forest stands and support the potential of the forestry industries. Conversely, remote, HNV forests can be set aside to protect biodiversity. Yet, regeneration of drought-tolerant species may gradually replace that of co-occurring, more vulnerable species (e.g., Hilmers et al. 2019; Torresan et al. 2020). Genetic materials more adapted to environmental modifications can also be tested and used. 


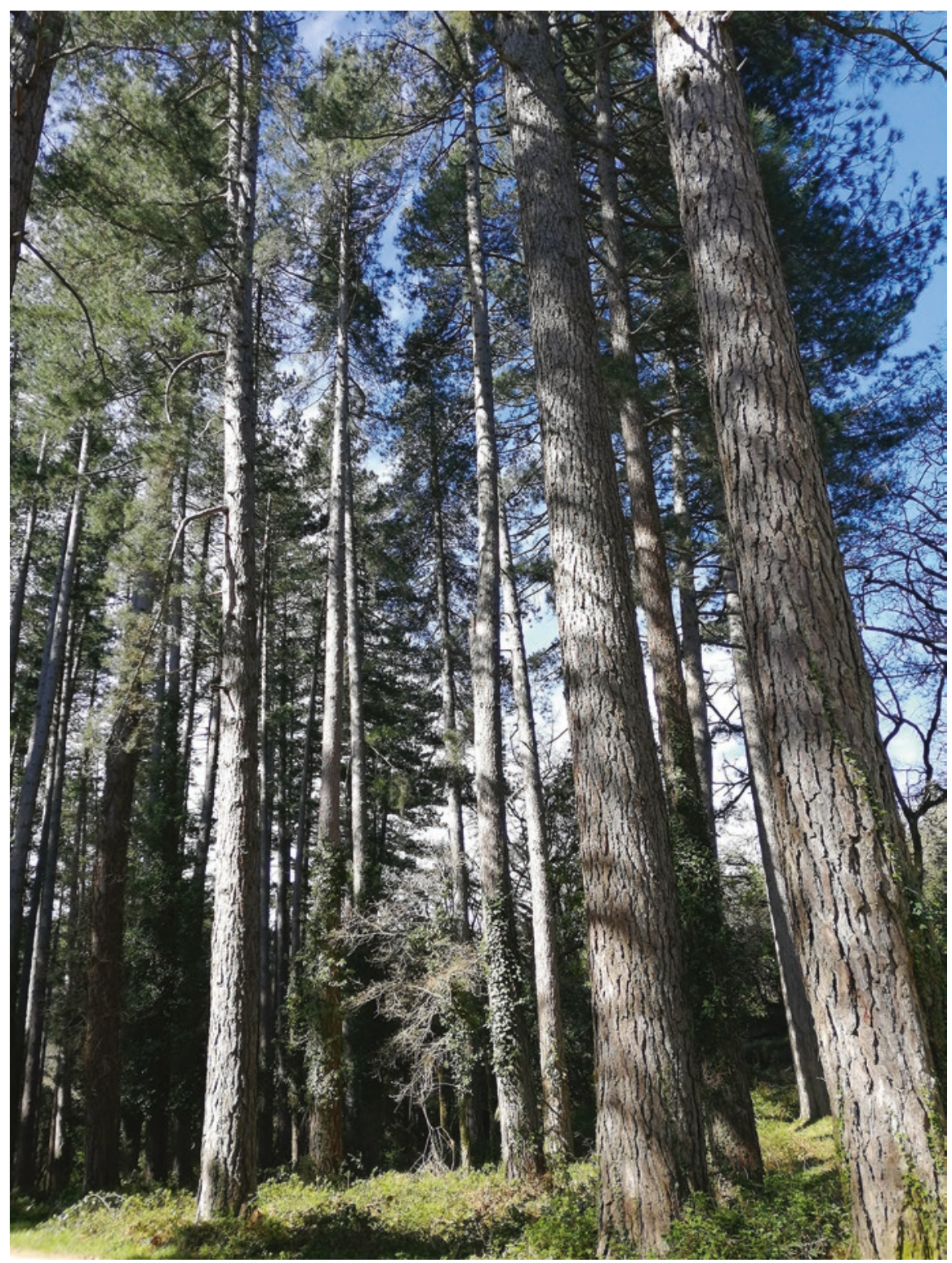

Fig. 1.12 "Aldo Pavari" permanent experimental plot of Pinus nigra ssp. laricio established in 1919; Foresta Demaniale di Fiorentini, Sardinia, Italy)

Permanent sampling forest plots are the basic unit of functional and structural indicator measurements. Their size may range, though experimental plots covering 1 ha $(100 \times 100 \mathrm{~m})$ can be considered suitable for simulating various forestry scenarios and their impacts on the provision of ecosystem services and/or the 
preservation of habitat diversity (Santopuoli et al. 2019). Within these plots, such as the Marteloscope (Bruciamacchie et al. 2005), all trees are counted, numbered, marked, and mapped in the census. Circular sampling subplots, with radii ranging from $4 \mathrm{~m}$ up to $20 \mathrm{~m}$, can then be considered to quantify specific indicators (Lombardi et al. 2015). Repeated measurements of differential forest traits, resulting from changes in governance or environment compared to a defined business-asusual scenario or normality mode, are needed to predict future forest ecosystem trajectories and new safe operating spaces (Johnstone et al. 2016). These measurements require that modular instruments (soil-plant-atmosphere continuum devices and ancillary sensors) are in place and monitoring methods are well established (Chave et al. 2019). Therefore, changes in patterns of tree growth and health status, as well as successional development and anthropogenic impact, can be recorded. The information is useful for planning observational networks or storing model data at different temporal and spatial scales. Since disturbances may shape the structure of forest stands, boundaries and dimensions of ecological or operational units vary over time, depending on environmental circumstances or management objectives to follow the natural stand dynamics (O'Hara and Nagel 2013).

\subsection{Putting Climate-Smart Forestry into Practice}

Climate-smart forestry integrates the overlaps, synergies, and trade-offs of global objectives and local needs into forest governance. Indeed, the vulnerability to climate change in the forest sector affects both rural communities and the international arena. Therefore, climate-smart forest strategies need to flow into policies on rural development, climate mitigation, and the bioeconomy. Climate-smart forestry may play an important role in strengthening the resilience of rural communities, by coordinating risk assessment, planning efforts, management activities, support policies, and incentive strategies. Understanding the role of CSF requires targeting specific areas of vulnerability, while maintaining a broad vision of forest-related options and their potential impacts on adaptation to and mitigation of climate change.

While climate change, disturbance regime, and unsustainable exploitation jeopardize natural ecosystems, nature-based solutions, including sustainable forest management, can be fundamental in combating climate and land-use changes (Seddon et al. 2019). Landowners, forest enterprises, and end users (in addition to decision makers, forest managers, and research scientists) are key actors in halting biodiversity loss, while benefiting from healthy forests. Reconciling the sustainable supply of economic goods with a wise demand of ecosystem services is crucial to build forest resilience and prevent landscape degradation. Climate-smart forestry approach focuses directly on forest functions and silvicultural systems by assessing the vulnerability of forest sustainable management objectives, recognizing the need to balance the three dimensions of development goals, that is, the economic, social, and environmental. This requires appropriate technological capacity for applying the conceptual framework in practice, which may form the basis of decision support 


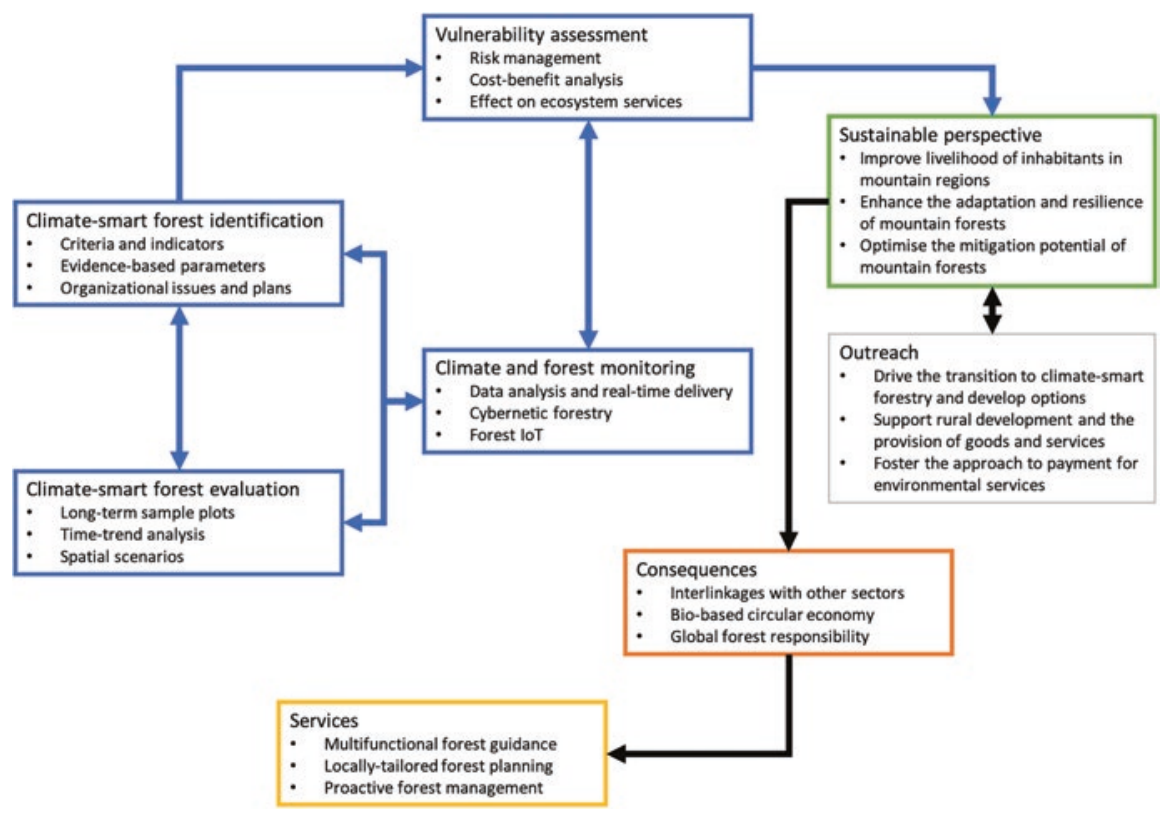

Fig. 1.13 Feedback diagram of the CSF approach

tools that assist in the development and implementation of climate-smart options in response to system-related vulnerabilities (Fig. 1.13).

Because forests provide essential ecosystem services, the inclusion of payment schemes for ecosystem services in adaptation plans needs to be strengthened. These schemes increase the adaptive capacity of vulnerable communities (like those of mountain areas) and provide an incentive mechanism for long-term sustainability (adoption of specific support measures). Climate-smart forestry needs to incorporate emerging technology, identifying gaps in capacity building of the forest sector and changes in development objectives of modern society. Assessing the impact of climate change on the forest sector is prerequisite to implement management options that increase the resilience of forest ecosystems and decrease the vulnerability of rural communities. As an example, forest roads are required to transport timber and other forest products to markets, generating income to local enterprises, but also to fight forest fires, reducing risk of extreme events. These efforts need to be crosssectoral and require multilevel actions to prepare effective responses of the forest sector to climate change.

Forest coverage varies considerably among Member States of the EU. In Finland and Sweden, forests cover more than $60 \%$ of the country, while only $11 \%$ in the Netherlands and the United Kingdom. Although the forest landscape has been largely shaped by man, in the EU, the area of land covered by forests is growing, as a result of both natural growth and afforestation work. Only $4 \%$ of the forested area can be considered pristine. However, as the Treaties make no specific reference to 
forests, the European Union does not have a common forestry policy. With the aims to ensure that Europe's forests are managed sustainably and to strengthen the EU's contribution to promoting sustainable forest management and tackling deforestation worldwide, the Commission set out a new EU Forest Strategy (beyond 2020). The new 2030 Biodiversity Strategy and the European Green Deal, developed by the Commission, are relevant opportunities to put the forest sector on the international agenda, provided that a common communication and collaboration plan is developed. Country-specific institutional context, in fact, may slow the implementation of new concepts, like CSF, aiming to assess climate change risks and implement forest adaptation strategies. A systematic approach to common monitoring and knowledge sharing across Europe is encouraged by COST (European Cooperation in Science and Technology), a funding organization for research and innovation networks enabling collaboration among researchers. Stronger coordination with institutional and operational levels is, however, essential for harmonizing assessment protocols, managing field trials, and transferring research results at the continental scale.

Establishment of a multidisciplinary partnership approach and commitment to long-term experimental plot management are keys to the success of CSF that aim to develop and test large-scale silvicultural alternatives (Nagel et al. 2017). Differences across European countries in terms of forest industry, governance quality, manager experience, investment capacity, and training system are challenges that need to be harmonized by a shared strategy. Cross-site analysis of standardized monitoring plot networks and perceived ecosystem service benefits in multifunctional forest landscapes, with varying spatial and temporal resolution, may improve our understanding of forest responses to chronic stresses, extreme events, and successional processes. A European forest network approach may provide examples of adaptation, mitigation, and production strategies, spanning a range of management and governance options. Evidence-informed management approach of threatened forests is key to help data-driven gradual transition to more stable ecosystems, as well as to fine-tune the provision of ecosystem services.

The application of CSF strategies and the bottom-up approach of the Nationally Determined Contributions (NDCs) in the Paris Agreement may help comply with the target of reducing climate risks. Nevertheless, the benefits from enhancing carbon sequestration through forest management can be counterbalanced or amplified by concurrent management-induced changes in complex forest-atmosphere interactions (Bravo et al. 2017). Therefore, managing forests for halting climate warming through mitigation may result only in compensating $\mathrm{CO}_{2}$ emissions. Carbon extraction and sequestration through bioenergy plantations, forest restoration, and urban forestry will not suffice alone to thin the atmospheric $\mathrm{CO}_{2}$ blanket and reduce the risk of $\mathrm{CO}_{2}$-induced global warming. Although these cost-effective land-based sink options may complement negative emission technologies, they are also vulnerable to both natural and anthropic disturbances. Should climate benefits from CSF remain important only on a local scale or in specific geographic circumstances (e.g., mountain environments), forest adaptation to changing climate will still be essential 
to sustain the provision of goods and services, while avoiding positive climate feedback from disturbances.

\section{References}

Aggestam F, Konczal A, Sotirov M et al (2020) Can nature conservation and wood production be reconciled in managed forests? A review of driving factors for integrated forest management in Europe. J Environ Manag 268:110670. https://doi.org/10.1016/j.jenvman.2020.110670

Allen CD, Macalady AK, Chenchouni $\mathrm{H}$ et al (2010) A global overview of drought and heatinduced tree mortality reveals emerging climate change risks for forests. For Ecol Manag 259:660-684. https://doi.org/10.1016/j.foreco.2009.09.001

Bálint M, Pfenninger M, Grossart H-P et al (2018) Environmental DNA time series in ecology. Trends Ecol Evol 33:945-957. https://doi.org/10.1016/j.tree.2018.09.003

Barcelo-Ordinas JM, Doudou M, Garcia-Vidal J, Badache N (2019) Self-calibration methods for uncontrolled environments in sensor networks: a reference survey. Ad Hoc Netw 88:142-159. https://doi.org/10.1016/j.adhoc.2019.01.008

Bauhus J, Puettmann KJ, Kühne C (2013) Close-to-nature forest management in Europe: does it support complexity and adaptability of forest ecosystems? In: Managing forests as complex adaptive systems. Routledge, pp 201-227

Bayne K, Damesin S, Evans M (2017) The internet of things - wireless sensor networks and their application to forestry. 61:5

Boisvert-Marsh L, Périé C, de Blois S (2014) Shifting with climate? Evidence for recent changes in tree species distribution at high latitudes. Ecosphere 5:art83. https://doi.org/10.1890/ ES14-00111.1

Bonan GB (2008) Forests and climate change: forcings, feedbacks, and the climate benefits of forests. Science 320:1444-1449

Bonsall MB, Froyd CA, Jeffers ES (2020) Resilience: nitrogen limitation, mycorrhiza and long-term palaeoecological plant-nutrient dynamics. Biol Lett 16:20190441. https://doi. org/10.1098/rsbl.2019.0441

Bowditch E, Santopuoli G, Binder F et al (2020) What is climate-smart forestry? A definition from a multinational collaborative process focused on mountain regions of Europe. Ecosyst Serv 43:101113. https://doi.org/10.1016/j.ecoser.2020.101113

Bravo F, Jandl R, LeMay V, von Gadow K (2017) Introduction. In: Bravo F, LeMay V, Jandl R (eds) Managing forest ecosystems: the challenge of climate change. Springer International Publishing, Cham, pp 3-12

Bravo-Oviedo A, Condés S, del Río M et al (2018) Maximum stand density strongly depends on species-specific wood stability, shade and drought tolerance. Forest Int J Forest Res 91:459-469. https://doi.org/10.1093/forestry/cpy006

Brocks S, Bendig J, Bareth G (2016) Toward an automated low-cost three-dimensional crop surface monitoring system using oblique stereo imagery from consumer-grade smart cameras. J Appl Remote Sens 10:046021. https://doi.org/10.1117/1.JRS.10.046021

Bruciamacchie M, Pierrat J-C, Tomasini J (2005) Modèles explicatif et marginal de la stratégie de martelage d'une parcelle irrégulière. Ann For Sci 62:727-736. https://doi.org/10.1051/ forest: 2005070

Cailleret M, Jansen S, Robert EMR et al (2017) A synthesis of radial growth patterns preceding tree mortality. Glob Change Biol 23:1675-1690. https://doi.org/10.1111/gcb.13535

Ceddia MG, Bardsley NO, Gomez-y-Paloma S, Sedlacek S (2014) Governance, agricultural intensification, and land sparing in tropical South America. Proc Natl Acad Sci 111:7242. https:// doi.org/10.1073/pnas.1317967111 
Chave J, Davies SJ, Phillips OL et al (2019) Ground data are essential for biomass remote sensing missions. Surv Geophys 40:863-880. https://doi.org/10.1007/s10712-019-09528-w

Ciancio O, Nocentini S (2011) Biodiversity conservation and systemic silviculture: concepts and applications. Plant Biosyst - Int J Deal Asp Plant Biol 145:411-418. https://doi.org/10.108 0/11263504.2011.558705

Clarke N, Fischer R, de Vries W et al (2011) Availability, accessibility, quality and comparability of monitoring data for European forests for use in air pollution and climate change science. IForest - Biogeosci Forestry 4:162-166. https://doi.org/10.3832/ifor0582-004

Coble AP, Vadeboncoeur MA, Berry ZC et al (2017) Are northeastern U.S. forests vulnerable to extreme drought? Ecol Process 6:34. https://doi.org/10.1186/s13717-017-0100-x

Crowther TW, Glick HB, Covey KR et al (2015) Mapping tree density at a global scale. Nature 525:201-205. https://doi.org/10.1038/nature14967

Curtis PG, Slay CM, Harris NL et al (2018) Classifying drivers of global forest loss. Science 361:1108-1111. https://doi.org/10.1126/science.aau3445

Davies AL, Smith MA, Froyd CA, McCulloch RD (2017) Microclimate variability and long-term persistence of fragmented woodland. Biol Conserv 213:95-105. https://doi.org/10.1016/j. biocon.2017.06.006

del Río M, Vergarechea M, Hilmers T et al (2021) Effects of elevation-dependent climate warming on intra- and inter-specific growth synchrony in mixed mountain forests. For Ecol Manag 479:118587. https://doi.org/10.1016/j.foreco.2020.118587

Dumroese RK, Williams MI, Stanturf JA, Clair JBS (2015) Considerations for restoring temperate forests of tomorrow: forest restoration, assisted migration, and bioengineering. New For 46:947-964. https://doi.org/10.1007/s11056-015-9504-6

European Environment Agency (2016) European forest ecosystems: state and trends. Publications Office, LU

FAO (2013) The state of food insecurity in the world. FAO, Rome

Franklin JF, Mitchell RJ, Palik BJ (2007) Natural disturbance and stand development principles for ecological forestry. U.S. Department of Agriculture, Forest Service, Northern Research Station, Newtown Square

Gabrys J (2020) Smart forests and data practices: from the internet of trees to planetary governance. Big Data Soc 7:2053951720904871. https://doi.org/10.1177/2053951720904871

Grassi G, Cescatti A, Matthews R et al (2019) On the realistic contribution of European forests to reach climate objectives. Carbon Balance Manag 14:8. https://doi.org/10.1186/ s13021-019-0123-y

Griscom BW, Adams J, Ellis PW et al (2017) Natural climate solutions. Proc Natl Acad Sci 114:11645-11650. https://doi.org/10.1073/pnas.1710465114

Halbritter AH, Boeck HJD, Eycott AE et al (2020) The handbook for standardized field and laboratory measurements in terrestrial climate change experiments and observational studies (ClimEx). Methods Ecol Evol 11:22-37. https://doi.org/10.1111/2041-210X.13331

Hamilton R, Brussel T, Asena Q et al (2018) Assessing the links between resilience, disturbance and functional traits in paleoecological datasets. Past Glob Chang Mag 26:87-87. https://doi. org/10.22498/pages.26.2.87

Hanewinkel M, Cullmann DA, Schelhaas M-J et al (2013) Climate change may cause severe loss in the economic value of European forest land. Nat Clim Chang 3:203-207. https://doi. org/10.1038/nclimate 1687

Hartmann H, Moura CF, Anderegg WRL et al (2018) Research frontiers for improving our understanding of drought-induced tree and forest mortality. New Phytol 218:15-28. https://doi. org/10.1111/nph.15048

Hilmers T, Avdagić A, Bartkowicz L et al (2019) The productivity of mixed mountain forests comprised of Fagus sylvatica, Picea abies, and Abies alba across Europe. Forestry Int J Forest Res 92:512-522. https://doi.org/10.1093/forestry/cpz035

Innes J (2009) Forest fragments need fencing and pest control. Open Space 75:15-16 
IPCC (2019) Climate change and land: an IPCC special report on climate change, desertification, land degradation, sustainable land management, food security, and greenhouse gas fluxes in terrestrial ecosystems, Geneva

Jandl R, Ledermann T, Kindermann G et al (2018) Strategies for climate-smart Forest Management in Austria. Forests 9:592. https://doi.org/10.3390/f9100592

Jõgiste K, Frelich LE, Laarmann D et al (2018) Imprints of management history on hemiboreal forest ecosystems in the Baltic States. Ecosphere 9:e02503. https://doi.org/10.1002/ecs2.2503

Johnstone JF, Allen CD, Franklin JF et al (2016) Changing disturbance regimes, ecological memory, and forest resilience. Front Ecol Environ 14:369-378. https://doi.org/10.1002/fee.1311

Kauppi P, Hanewinkel M, Lundmark T et al (2018) Climate smart forestry in Europe. European Forest Institute, Joensuu

Larsen JB (1995) Ecological stability of forests and sustainable silviculture. For Ecol Manag 73:85-96. https://doi.org/10.1016/0378-1127(94)03501-M

Lindner M, Maroschek M, Netherer S et al (2010) Climate change impacts, adaptive capacity, and vulnerability of European forest ecosystems. For Ecol Manag 259:698-709. https://doi. org/10.1016/j.foreco.2009.09.023

Lindner M, Fitzgerald JB, Zimmermann NE et al (2014) Climate change and European forests: what do we know, what are the uncertainties, and what are the implications for forest management? J Environ Manag 146:69-83. https://doi.org/10.1016/j.jenvman.2014.07.030

Lipper L, Thornton P, Campbell BM et al (2014) Climate-smart agriculture for food security. Nat Clim Chang 4:1068-1072. https://doi.org/10.1038/nclimate2437

Lombardi F, Marchetti M, Corona P et al (2015) Quantifying the effect of sampling plot size on the estimation of structural indicators in old-growth forest stands. For Ecol Manag 346:89-97. https://doi.org/10.1016/j.foreco.2015.02.011

Luyssaert S, Schulze E-D, Börner A et al (2008) Old-growth forests as global carbon sinks. Nature 455:213-215. https://doi.org/10.1038/nature07276

Luyssaert S, Marie G, Valade A et al (2018) Trade-offs in using European forests to meet climate objectives. Nature 562:259-262. https://doi.org/10.1038/s41586-018-0577-1

McDowell NG, Allen CD, Anderson-Teixeira K et al (2020) Pervasive shifts in forest dynamics in a changing world. Science 368:eaaz9463. https://doi.org/10.1126/science.aaz9463

Messier C, Bauhus J, Doyon F et al (2019) The functional complex network approach to foster forest resilience to global changes. Forest Ecosyst 6:21. https://doi.org/10.1186/s40663-019-0166-2

Millar CI, Stephenson NL (2015) Temperate forest health in an era of emerging megadisturbance. Science 349:823-826

Millar CI, Stephenson NL, Stephens SL (2007) Climate change and forests of the future: managing in the face of uncertainty. Ecol Appl 17:2145-2151. https://doi.org/10.1890/06-1715.1

Millar CI, Swanston CW, Peterson DL (2014) Adapting to climate change. In: Peterson DL, Vose JM, Patel-Weynand T (eds) Climate change and United States forests. Springer Netherlands, Dordrecht, pp 183-222

Moffat AM, Papale D, Reichstein M et al (2007) Comprehensive comparison of gap-filling techniques for eddy covariance net carbon fluxes. Agric For Meteorol 147:209-232. https://doi. org/10.1016/j.agrformet.2007.08.011

Nabuurs G-J, Lindner M, Verkerk PJ et al (2013) First signs of carbon sink saturation in European forest biomass. Nat Clim Chang 3:792-796. https://doi.org/10.1038/nclimate1853

Nabuurs G-J, Verkerk PJ, Schelhaas M-J et al (2018) Climate-smart forestry: mitigation impacts in three European regions. European Forest Institute

Nabuurs G-J, Verweij P, Van Eupen M et al (2019) Next-generation information to support a sustainable course for European forests. Nat Sustain 2:815-818. https://doi.org/10.1038/ s41893-019-0374-3

Nagel LM, Palik BJ, Battaglia MA et al (2017) Adaptive Silviculture for climate change: a National Experiment in manager-scientist partnerships to apply an adaptation framework. J For 115:167-178. https://doi.org/10.5849/jof.16-039 
Nikinmaa L, Lindner M, Cantarello E et al (2020) Reviewing the use of resilience concepts in Forest sciences. Curr For Rep 6:61-80. https://doi.org/10.1007/s40725-020-00110-x

Nocentini S (2015) Managing forests as complex adaptive systems: an issue of theory and method. In: Proceedings of the second international congress of Silviculture. Accademia Italiana di Scienze Forestali, Florence, pp 913-918

O'Hara KL, Nagel LM (2013) The stand: revisiting a central concept in forestry. J For 111:335-340. https://doi.org/10.5849/jof.12-114

O'Hara KL, Ramage BS (2013) Silviculture in an uncertain world: utilizing multi-aged management systems to integrate disturbance $\dagger$. For Int J For Res 86:401-410. https://doi.org/10.1093/ forestry/cpt012

Ogden AE, Innes J (2007) Incorporating climate change adaptation considerations into forest management planning in the boreal forest. Int For Rev 9:713-733

Phalan B, Onial M, Balmford A, Green RE (2011) Reconciling food production and biodiversity conservation: land sharing and land sparing compared. Science 333:1289-1291. https://doi. org/10.1126/science. 1208742

Phalan B, Green RE, Dicks LV et al (2016) How can higher-yield farming help to spare nature? Science 351:450-451. https://doi.org/10.1126/science.aad0055

Pommerening A, Murphy ST (2004) A review of the history, definitions and methods of continuous cover forestry with special attention to afforestation and restocking. For Int J For Res 77:27-44. https://doi.org/10.1093/forestry/77.1.27

Pretzsch H, Rötzer T, Forrester DI (2017) Modelling mixed-species Forest stands. In: Pretzsch H, Forrester DI, Bauhus J (eds) Mixed-species forests: ecology and management. Springer, Berlin/Heidelberg, pp 383-431

Pretzsch H, Hilmers T, Biber P et al (2020) Evidence of elevation-specific growth changes of spruce, fir, and beech in European mixed mountain forests during the last three centuries. Can J For Res. https://doi.org/10.1139/cjfr-2019-0368

Price M, Gratzer G, Alemayehu Duguma L, et al (2011) Mountain Forests in a Changing World: realizing values, adressing challenges. Food and Agriculture Organization of the United Nations (FAO) and Centre of ...

Puettmann KJ, Coates D, Messier C (2009) A critique of Silviculture: managing for complexity. Island press, Washington DC

Puettmann KJ, Wilson SM, Baker SC et al (2015) Silvicultural alternatives to conventional even-aged forest management - what limits global adoption? For Ecosyst 2:8. https://doi. org/10.1186/s40663-015-0031-x

Rebmann C, Aubinet M, Schmid H et al (2018) ICOS eddy covariance flux-station site setup: a review. Int Agrophysics 32:471-494. https://doi.org/10.1515/intag-2017-0044

Rull V (2014) Time continuum and true long-term ecology: from theory to practice. Front Ecol Evol 2. https://doi.org/10.3389/fevo.2014.00075

Rundel PW, Graham EA, Allen MF et al (2009) Environmental sensor networks in ecological research. New Phytol 182:589-607. https://doi.org/10.1111/j.1469-8137.2009.02811.x

Sabatini FM, Burrascano S, Keeton WS et al (2018) Where are Europe's last primary forests? Divers Distrib 24:1426-1439. https://doi.org/10.1111/ddi.12778

Santopuoli G, di Cristofaro M, Kraus D et al (2019) Biodiversity conservation and wood production in a Natura 2000 Mediterranean forest. A trade-off evaluation focused on the occurrence of microhabitats. IForest - Biogeosciences For 12:76. https://doi.org/10.3832/ifor2617-011

Santopuoli G, Temperli C, Alberdi I et al (2020) Pan-European sustainable forest management indicators for assessing climate-smart forestry in Europe 1. Can J For Res. https://doi. org/10.1139/cjfr-2020-0166

Seddon N, Turner B, Berry P et al (2019) Grounding nature-based climate solutions in sound biodiversity science. Nat Clim Chang 9:84-87. https://doi.org/10.1038/s41558-019-0405-0

Seidl R, Rammer W, Spies TA (2014) Disturbance legacies increase the resilience of forest ecosystem structure, composition, and functioning. Ecol Appl 24:2063-2077. https://doi. org/10.1890/14-0255.1 
Seidl R, Spies TA, Peterson DL et al (2016) REVIEW: searching for resilience: addressing the impacts of changing disturbance regimes on forest ecosystem services. J Appl Ecol 53:120-129. https://doi.org/10.1111/1365-2664.12511

Seymour RS, Hunter ML (1999) Principles of ecological forestry. In: Hunter ML (ed) Maintaining biodiversity in Forest ecosystems. Cambridge University Press, Cambridge, pp 22-62

Šimpraga M, Ghimire RP, Van Der Straeten D et al (2019) Unravelling the functions of biogenic volatiles in boreal and temperate forest ecosystems. Eur J For Res 138:763-787. https://doi. org/10.1007/s10342-019-01213-2

Steppe K, Sterck F, Deslauriers A (2015) Diel growth dynamics in tree stems: linking anatomy and ecophysiology. Trends Plant Sci 20:335-343

Tognetti R, Scarascia Mugnozza G, Hofer T (2017) Mountain watersheds and ecosystem services: balancing multiple demand of forest management in head-watersheds. European Forest Institute

Torresan C, del Río M, Hilmers T et al (2020) Importance of tree species size dominance and heterogeneity on the productivity of spruce-fir-beech mountain forest stands in Europe. For Ecol Manag 457:117716. https://doi.org/10.1016/j.foreco.2019.117716

Torresan C, Benito Garzon M, O'Grady M et al (2021) A new generation of sensors and monitoring tools to support climate-smart forestry practices. Can J For Res. https://doi.org/10.1139/ cjfr-2020-0295

Tscharntke T, Clough Y, Wanger TC et al (2012) Global food security, biodiversity conservation and the future of agricultural intensification. Biol Conserv 151:53-59. https://doi.org/10.1016/j. biocon.2012.01.068

Valentini R, Marchesini LB, Gianelle D et al (2019) New tree monitoring systems: from industry 4.0 to nature 4.0. Ann Silvic Res 43:84-88. https://doi.org/10.12899/asr-1847

Verkerk PJ, Costanza R, Hetemäki L et al (2020) Climate-smart forestry: the missing link. For Policy Econ 115:102164. https://doi.org/10.1016/j.forpol.2020.102164

Vose JM, Peterson DL, Domke GM, et al (2018) Forests. U.S. Global Change Research Program

Willis KJ, Bailey RM, Bhagwat SA, Birks HJB (2010) Biodiversity baselines, thresholds and resilience: testing predictions and assumptions using palaeoecological data. Trends Ecol Evol 25:583-591. https://doi.org/10.1016/j.tree.2010.07.006

Wolfslehner B, Linser S, Pülzl H et al (2016) Forest bioeconomy - a new scope for sustainability indicators. European Forest Institute

Zellweger F, De Frenne P, Lenoir J et al (2019) Advances in microclimate ecology arising from remote sensing. Trends Ecol Evol 34:327-341. https://doi.org/10.1016/j.tree.2018.12.012

Open Access This chapter is licensed under the terms of the Creative Commons Attribution 4.0 International License (http://creativecommons.org/licenses/by/4.0/), which permits use, sharing, adaptation, distribution and reproduction in any medium or format, as long as you give appropriate credit to the original author(s) and the source, provide a link to the Creative Commons license and indicate if changes were made.

The images or other third party material in this chapter are included in the chapter's Creative Commons license, unless indicated otherwise in a credit line to the material. If material is not included in the chapter's Creative Commons license and your intended use is not permitted by statutory regulation or exceeds the permitted use, you will need to obtain permission directly from the copyright holder.

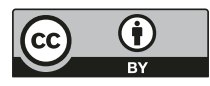

